\title{
New species of Neogene radiolarians from the Southern Ocean
}

\author{
JOHAN RENAUDIE* \& DAVID B. LAZARUS \\ Museum für Naturkunde, Leibniz-Institut für Evolutions- und Biodiversitätsforschung an der Humboldt-Universität zu Berlin, \\ Invalidenstraße 43, 10115 Berlin, Germany \\ *Corresponding author (e-mail: johan.renaudie@mfn-berlin.de)
}

\begin{abstract}
Antarctic Neogene radiolarians are abundant and have great potential for biostratigraphy and evolutionary research. Many of the species found in sediments have not yet been described and are thus unavailable for research purposes. In the first of a planned series, 24 new species of Antarctic Neogene radiolarians are described herein: two entactinarians (Orodapis hericina and Orodapis? ferrealuma), two spumellarians (Actinomma nigriniae and Carposphaera? annikae) and twenty nassellarians (Acrosphaera cuniculiauris, Amphimelissa? hibernifortuna, Antarctissa ballista, Artostrobus semazen, Botryopera gibbera, Carpocanium? uburex, Ceratocyrtis dolvenae, Cystophormis gargantua, Dendrospyris jobstae, Dictyophimus? kiwi, Dictyophimus larus, Gondwanaria clarae, Lithomelissa vespa, Lophophaena leberu, Siphonosphaera abelmannae, Siphostichartus jahnae, Spirocyrtis? hollisi, Stichophormis? cheni, Syscioscenium? wabisabi, Trisulcus pinguiculus). J. Micropalaeontol. 31(1): 29-52, February 2012.
\end{abstract}

KEYWORDS: Radiolaria, Polycystinea, Antarctic, Cenozoic, taxonomy

\section{INTRODUCTION}

The Southern Ocean today is a key component of the world's climate system, mixing bottom and surface waters from all parts of the world ocean, and regulating thermal exchange between the lower latitudes and the ice-sheets of the Antarctic continental interior. This ocean is also home to a diverse, highly endemic benthic and planktonic biota, whose evolution is poorly known. How this key environment came to be, how it may be changed by - or itself alter - anthropogenic global warming are important scientific questions. The Neogene sediments of the Southern Ocean record the development of this system. They document a complex, highly dynamic history of environmental and biological change, leading from relatively mild conditions in the Early Miocene to major shifts in ocean conditions in the mid-Miocene, near the Miocene-Pliocene boundary and in the Plio-Pleistocene (Kennett, 1995). This sedimentary record is poor in carbonate and the diversity of carbonate-shelled microfossils is low. This limits not only studies based on carbonate microfossils but also many geochemical proxies derived from microfossil carbonate. Instead, the Neogene Southern Ocean environmental and biological record is preserved primarily in the form of fossil diatoms and radiolarians. Thus, our ability to understand past and, to some degree, future environmental and biological change in this region is linked to our ability to make use of these fossil forms.

Radiolarians, in particular, have been extensively used in studies of past Southern Ocean conditions, both to provide a biostratigraphical framework for dating sediments and to reconstruct environmental conditions in past geological intervals (Lazarus, 1990, 1992). Unfortunately, despite this body of prior work, even the most basic knowledge of these fossils - their descriptive species taxonomy - is still highly incomplete. Individual studies have documented many species as part of more general work on biostratigraphy (Popofsky, 1908; Chen, 1975; Petrushevskaya, 1975; Caulet, 1986, 1991; Abelmann, 1990, 1992b; Lazarus, 1990, 1992) and the more common species encountered in the water column have been summarized by Abelmann (1992a). There have also been a small number of more purely taxonomic works for individual groups of taxa, such as the antarctissids (Petrushevskaya, 1986), cycladophorids (Lombari \& Lazarus, 1988) and 'prunoid' spumellarians (Lazarus et al., 2005). None the less, the majority of forms encountered on typical radiolarian slides from the Antarctic Neogene have remained undescribed until now and, thus, unusable for biostratigraphical, palaeoenvironmental or palaeobiological research. In this paper we begin a series of planned papers documenting the full species-level taxonomy of the Antarctic Neogene Radiolaria. This taxonomic work is part of a larger study on the evolution of this biota and the application of full faunal stratigraphic range data to high-resolution quantitative biostratigraphy. Here we describe 24 new species of radiolarians encountered in our work.

\section{MATERIAL AND METHODS}

All observed samples (c. 200) come from Ocean Drilling Project (ODP) materials, mostly from the Kerguelen-Heard Plateau (Leg 119, Sites 737, 738, 744, 745 and 746 and Leg 120, Sites 747, 748 and 750) with the addition of a few earliest Miocene samples from the Atlantic sector of the Southern Ocean (Leg 113, Site 690) (Fig. 1). Prepared slides were drawn from the junior author's collection. Samples were prepared using standard methods (Moore, 1973) using either $63 \mu \mathrm{m}$ or $45 \mu \mathrm{m}$ sieves.

The radiolarian biozonation follows Abelmann (1992b) and Lazarus (1992). The age estimates used for the range chart (Fig. 2) are inferred linearly from an age model based on Gersonde et al. (1990) for Leg 113, Barron et al. (1991) for Leg 119 and Harwood et al. (1992) for Leg 120. The relative abundances given in the range chart are drawn from counts made on $45 \mu \mathrm{m}$ strewn slides for 43 of the c. 200 samples. Measurements were made on specimen pictures using ImageJ (Abramoff et al., 2004): the range of variation and the mean (between brackets) are both given in $\mu \mathrm{m}$ under the 'Dimensions' section of each species.

The terminology used here follows mostly Jörgensen (1905) and Petrushevskaya $(1965,1968)$ for nassellarian internal structure (see Fig. 3), Goll (1968) for features specific to the family Trissocyclidae, and Boltovskoy (1998) for general external characters. Unless stated otherwise, the notation for connecting arches 


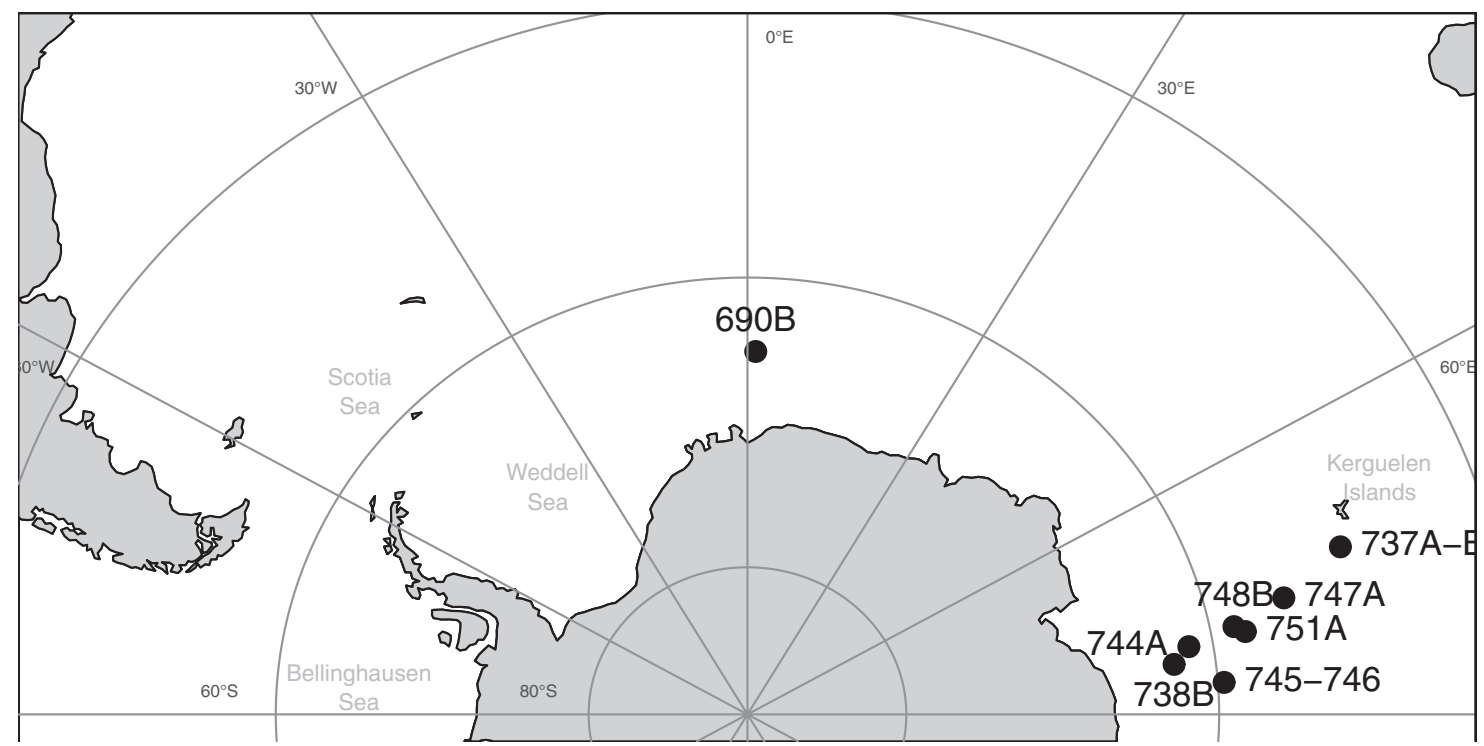

Fig. 1. Location of studied sites. Map created using R along with package GEOmap (Lees, 2010).

in nassellarians follows De Wever et al. (1979), Dumitrica (1991) and Funakawa (1995) in which they are named after a combination of the initials of the spines they originate from (i.e. arch AV would be an arch connecting spine A and spine V, Fig. 3).

All holotypes are deposited in the micropaleontology collection of the Museum für Naturkunde, Berlin. Specimens are identified by circles on the slides.

\section{SYSTEMATIC PALAEONTOLOGY}

Phylum Rhizaria Cavalier-Smith, 2002

Class Radiolaria Müller, 1858

Superorder Polycystinea Ehrenberg, 1838, emend. Riedel, 1967

Order Entactinaria Kozur \& Möstler, 1982

Family Orosphaeridae Haeckel, 1887

Genus Orodapis Friend \& Riedel, 1967

Type species. Orodapis spongiosa Friend \& Riedel, 1967

\section{Orodapis hericina $\mathrm{n}$. sp.}

(P1. 1, figs $1 \mathrm{~A}-\mathrm{C}, 3,4)$

Derivation of name. hericina is Latin for 'of the hedgehog'.

Diagnosis. Spherical cortical shell with six large spines and thorns at each bar node; medullary spicule with arches joining each of the radial beams.

Holotype. Plate 1, figs 1A-C; sample 120-748B-6H-CC (Early Miocene); ECO-029.

Material. 328 specimens (including broken specimens) were observed from ODP Sites 690, 744, 748 and 751.

Description. Large, thick, spherical, latticed cortical shell. Pores are irregular in size and in shape, and irregularly distributed. Each bar node bears a radially orientated, short, conical thorn. Medullary shell consists of a somewhat octahedral spicule from which arise six radial beams that reach the cortical shell and continue as more or less developed tri- or tetraradiate, serrated spines with a large basis. Arches link each of the radial beams a little further from the centre of the medullary shell $(c .40 \mu \mathrm{m})$.

Dimensions. Based on six specimens. Shell diameter: 440-590 $\mu \mathrm{m}$ $(515 \mu \mathrm{m})$.

Occurrence. Common from the $C$. antiqua to the $C$. golli regipileus Zone (Early Miocene) and rare from the E. punctatum to the A. golownini Zone (Early to Middle Miocene).

Remarks. Orodapis hericina differs from $O$. spongiosa in the medullary spicule lying at the middle of the cortical shell cavity, in the arches joining the beams, in the lattice wall of the cortical shell being simpler and in the shape of the main spines.

Orodapis? ferrealuma n. sp.

(Pl. 1, figs 2A-D, 5)

Derivation of name. From the Latin words ferrea, meaning 'made of iron' and luma, 'brambles': ferrealuma, therefore, stands for 'iron brambles, i.e. barbed wires.

Diagnosis. Cortical meshwork made of spiny bars; twelve serrated spines.

Holotype. Plate 1, figs 2A-D; sample 120-747A-2H-5 45/47 cm (Late Pliocene); ECO-031.

Material. 546 specimens (including identifiable fragments and broken specimens) were observed from ODP Sites 738, 744, 747, 748 and 751.

Description. Cortical shell is a nearly spherical icosahedron made of a meshwork of relatively thick, spiny anastomosed bars. The medullary shell is situated approximately at the centre of the 


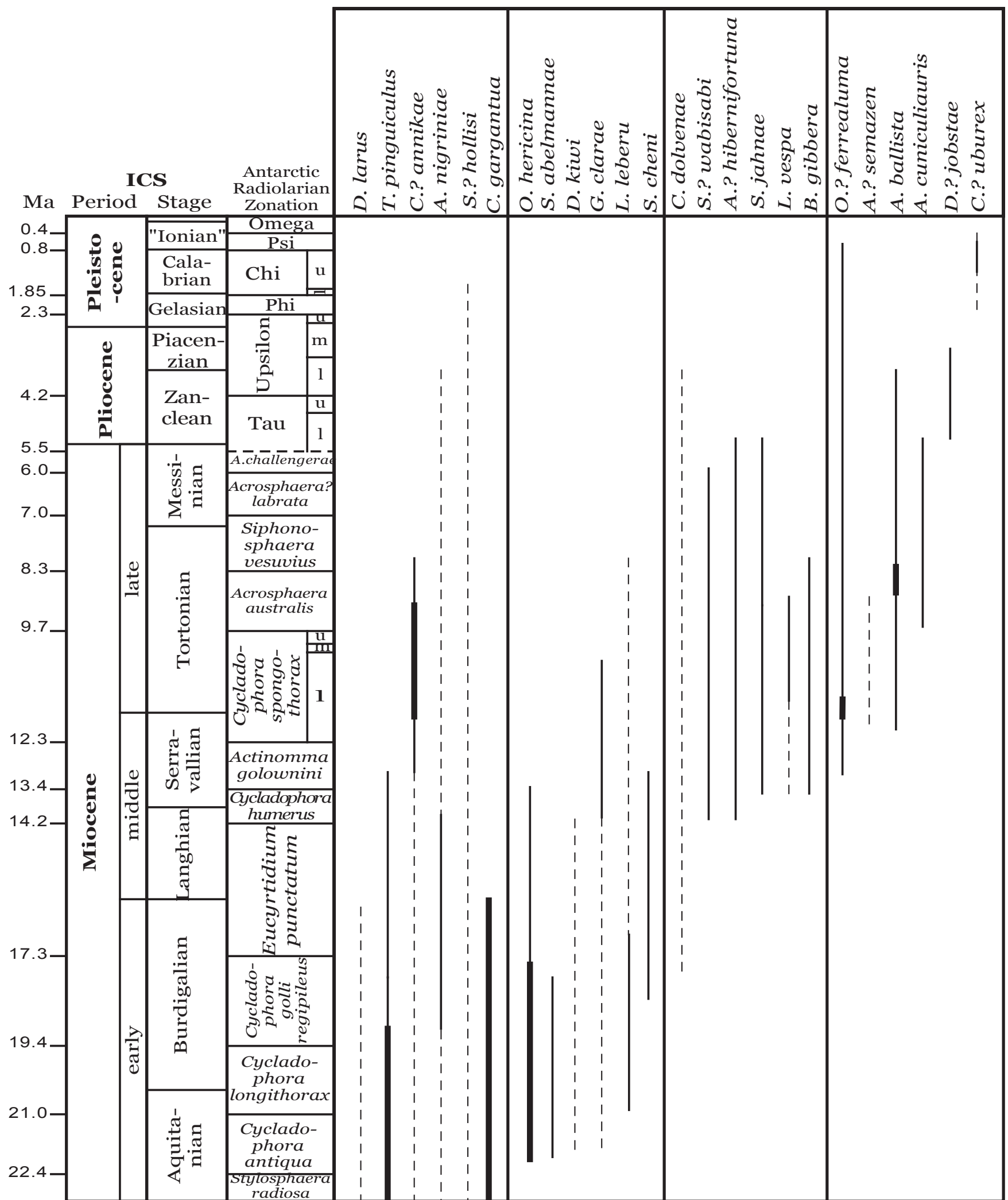

Fig. 2. Range chart of the 24 new species described herein. Antarctic radiolarian zonation follows Abelmann (1992b) and Lazarus (1992). Numerical age of zonal boundary after Lazarus (1992). Width of bars corresponds to a rough estimate of the species abundance: dashed line is 'sporadic', plain line 'rare' $(<0.5 \%$ of the assemblages) and bold line 'common' $(>0.5 \%)$. A. challengerae, Amphymenium challengerae; $\mathrm{u}$, upper; $\mathrm{m}$, middle; 1 , lower. 

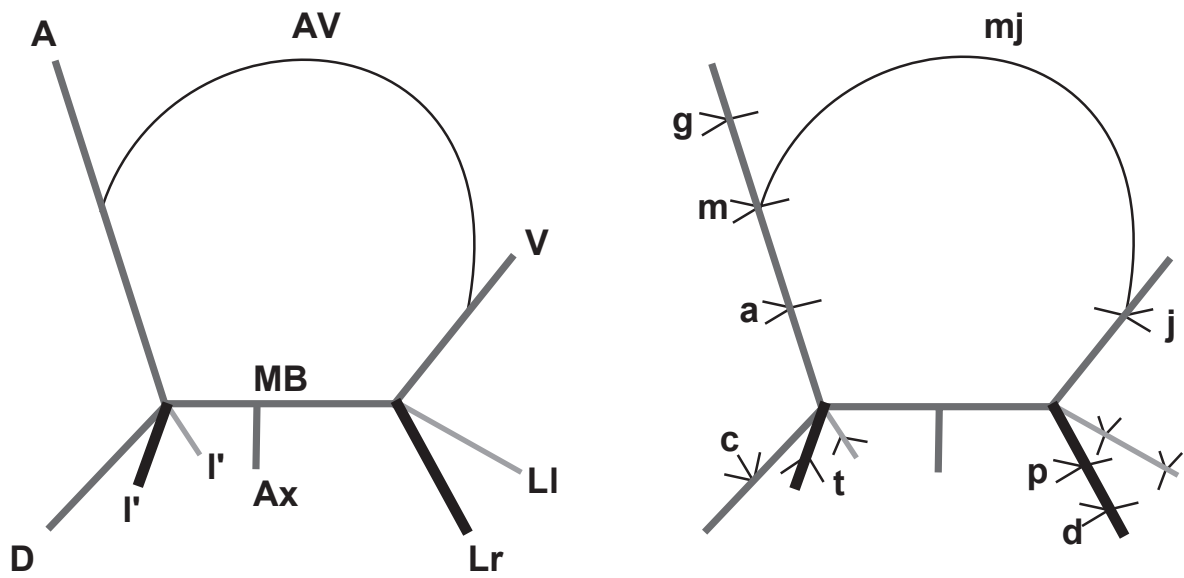

Fig. 3. Schematic illustrations of nassellarian cephalic inner structure. (Left) Initial spicule (modified after Jörgensen, 1905). A, apical spine; V, ventral or vertical spine; D, dorsal spine; Lr and L1, lateral spines; 1', secondary lateral spine; MB, median bar; Ax, axobate; AV, arch connecting spine A and spine V. Dark grey, spines in the sagittal plane (i.e. the plane of A, MB, D and V); black, spines on our side of the sagittal plane; light grey, spines on the other side of the sagittal plane. (Right) Apophyses (modified after Petrushevskaya, 1971). g, galear; m, mitral; a, anterior; t, tergal; c, cervical; p, pectoral; j, jugal; d, second serie of apophyses on spines Ll and Lr; $\mathrm{mj}$, arch connecting apophyses $\mathrm{m}$ and $\mathrm{j}$.

cortical shell cavity and is a somewhat octahedral spicule from which arise six thin radial beams that connect to the cortical shell at six of its vertices and continue outside as long, tribladed or conical, serrated spines. Between the medullary and the cortical shell lies a thin and sparse meshwork of anastomosed bars that diverge from those radial beams. There are six other radial spines, similar in shape and length to the six main radial spines, that arise from the six other vertices and that seem to root in the median meshwork. The bases of the twelve spines are thickened by the cortical meshwork that is overgrowing along them.

Dimensions. Based on five specimens. Shell diameter: 430-600 $\mu \mathrm{m}(510 \mu \mathrm{m})$.

Occurrence. Rare from the A golownini to the Psi Zone (Middle Miocene to Pleistocene); appears mostly as fragments.

Remarks. Orodapis? ferrealuma differs from O. hericina n. sp. and $O$. spongiosa in having this polyhedral outline instead of being nearly spherical as they are.

Order Spumellaria Ehrenberg, 1876

Family Actinommidae Haeckel 1862, emend. Sanfilippo \& Riedel, 1980

Genus Actinomma Haeckel, 1862, emend. Bjørklund, 1976b

Type species. Haliomma trinacrium Haeckel, 1860

Actinomma nigriniae n. sp.

(Pl. 2, figs $1 \mathrm{~A}-2 \mathrm{~B}$ and $6 \mathrm{~A}-\mathrm{B})$

Derivation of name. In memory of Catherine Nigrini for her numerous contributions to radiolarian research.

Diagnosis. Spherical cortical shell; twelve evenly-distributed radial beams protruding as twelve tribladed spines.
Holotype. Plate 2, figs 1A-B; sample 120-751A-13H-2 98/102 cm (Middle Miocene); ECO-032.

Material. 147 specimens (including identifiable fragments and broken specimens) were observed from ODP Sites 690, 738, 744, 747,748 and 751.

Description. Three concentric shells linked together by twelve tribladed radial beams that continue outside the cortical shell as twelve strongly tribladed radial spines. The innermost shell is an irregular sphere that tends to have a regular icosahedral (polygon having 20 faces) outline where each summit is linked to a radial beam. The median shell is approximately twice as big and has the same outline as the latter, except that the edges are smoother and therefore the shell is closer to a sphere. Pores are numerous, polygonal (penta- or hexagonal) and separated by thin bars. The outermost shell is approximately three times bigger than the median one and has an almost perfectly spherical outline. Pores on this shell are rounded, approximately equal in size and in shape, distributed according to a hexagonal pattern and separated by thin, rough, crested bars with raised nodes.

Dimensions. Based on five specimens. Cortical shell diameter: 130-145 $\mu \mathrm{m}(140 \mu \mathrm{m})$; outer medullary shell diameter: 45-60 $\mu \mathrm{m}$ (53 $\mu \mathrm{m})$; inner medullary shell diameter: 20-25 $\mu \mathrm{m}(22 \mu \mathrm{m})$; length of spines: $50-95 \mu \mathrm{m}(73 \mu \mathrm{m})$.

Occurrence. Rare to common from the $S$. radiosa to the $C$. humerus Zone (Early to Middle Miocene), sporadic from the $A$. golownini to the Upsilon Zone (Middle Miocene to Late Pliocene).

Remarks. Actinomma nigriniae differs from A. golownini Petrushevskaya, 1975 in the spherical shape of its cortical shell and in its smaller, more numerous, smaller pores. Furthermore every single one of the external spines is connected to the outer medullary shell, whereas in A. golownini only six of them are connected. 

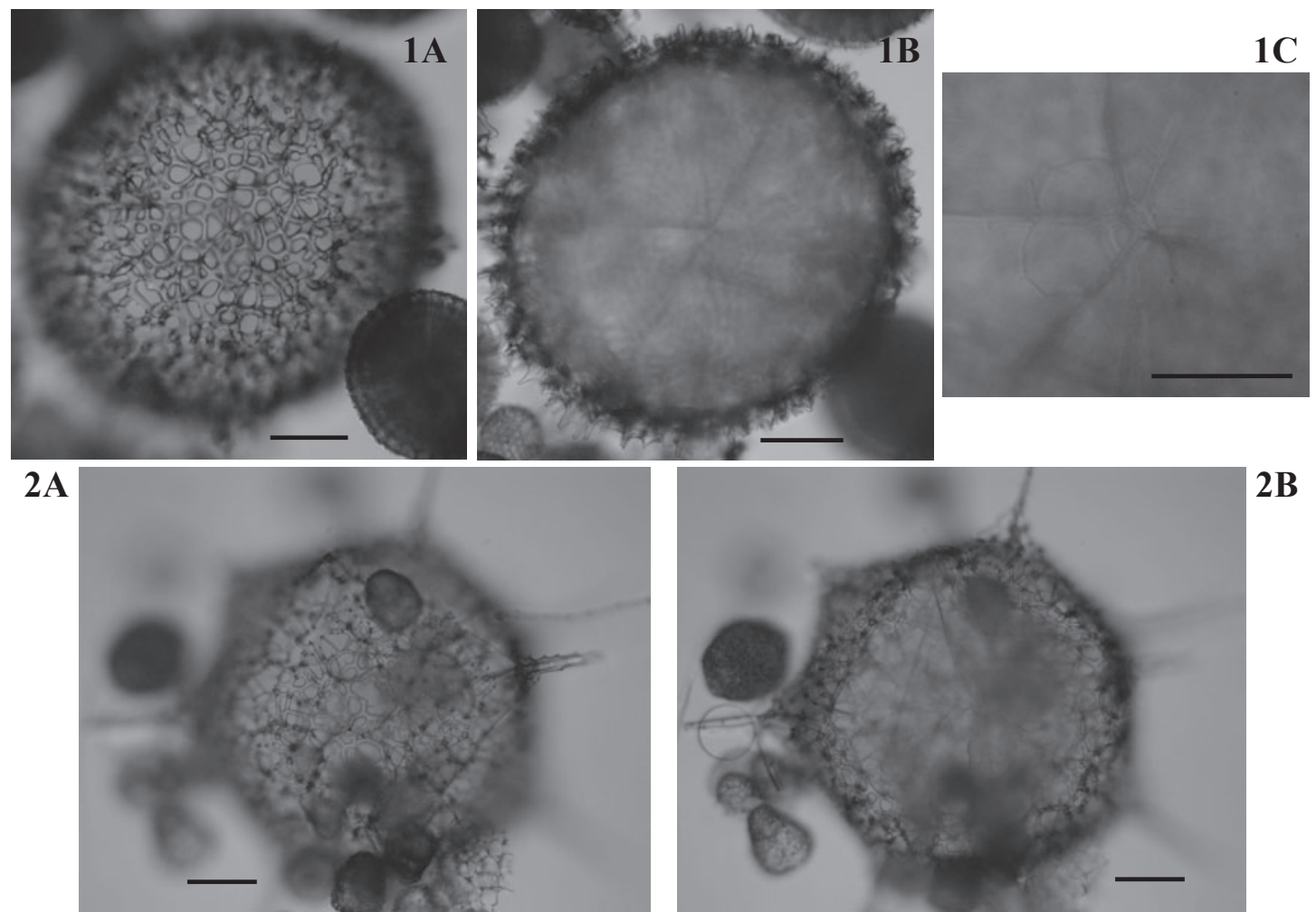

2B
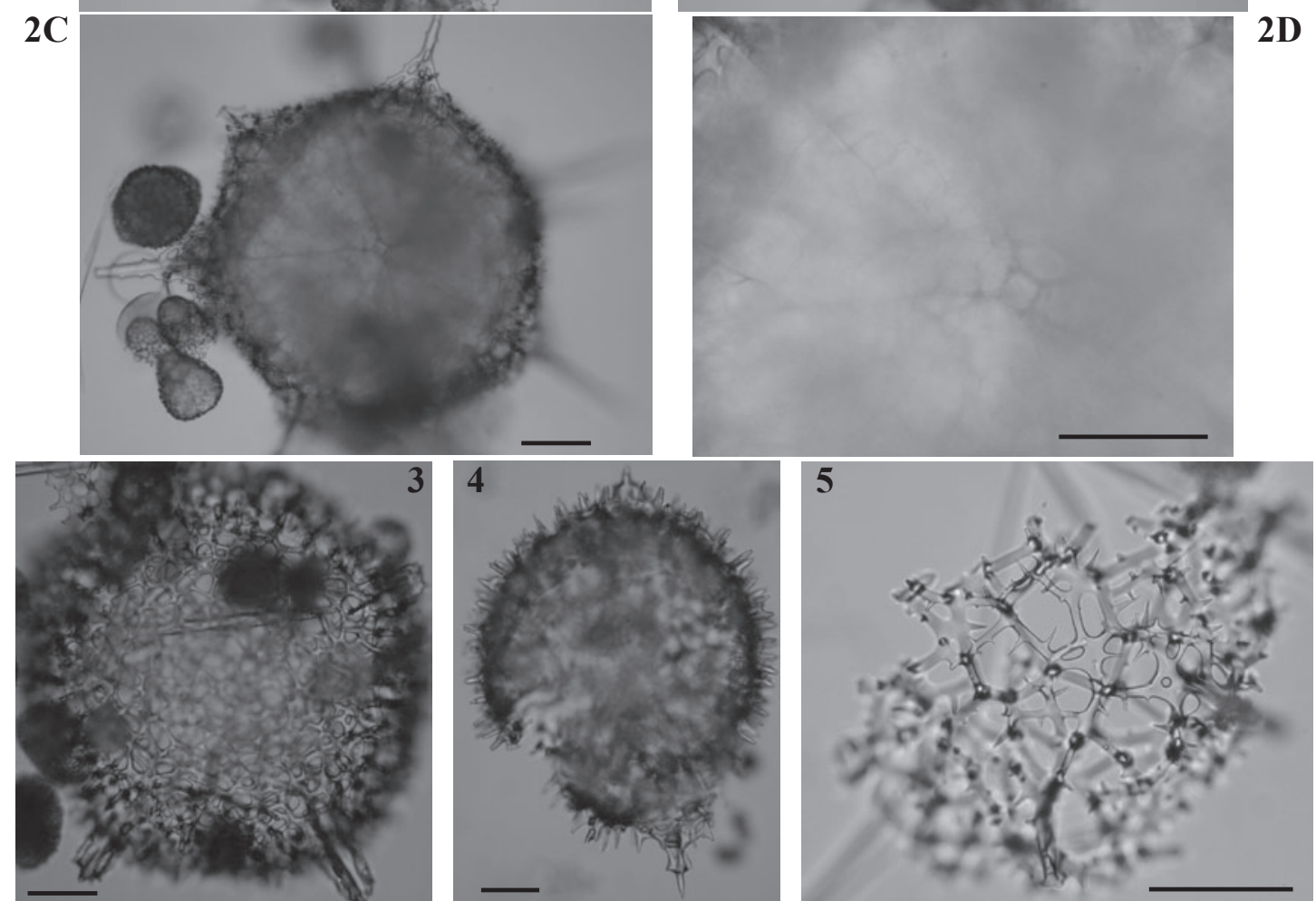

Explanation of Plate 1.

figs $\mathbf{1}, \mathbf{3}, \mathbf{4}$. Orodapis hericina $\mathrm{n}$. sp.: 1A, view of cortical shell surface; $\mathbf{1 B}$, view of medullary shell; $\mathbf{1 C}$, focus on medullary shell (all holotype, sample 120-748B-6H-CC); 3, sample 120-748B-6H-7, 45/47 cm; 4, broken specimen (sample 113-690B-6H-4, 22/24 cm). figs 2, 5. Orodapis? ferrealuma n. sp.: 2A, view of cortical shell surface; 2B, view of intermediate meshwork; 2C, view of medullary shell; 2D, focus on medullary shell (all holotype, sample 120-747A-2H-5, 45/47 cm); 5, fragment (sample 119-744A-2H-1, 53/55 cm). All scale bars $100 \mu \mathrm{m}$ except for $1 \mathrm{C}$ and $2 \mathrm{D}$ where scale bars represent $50 \mu \mathrm{m}$. Magnification $\times 96$ on all except $1 \mathrm{C}$ and $2 \mathrm{D}(\times 384)$ and 5 $(\times 192)$. 

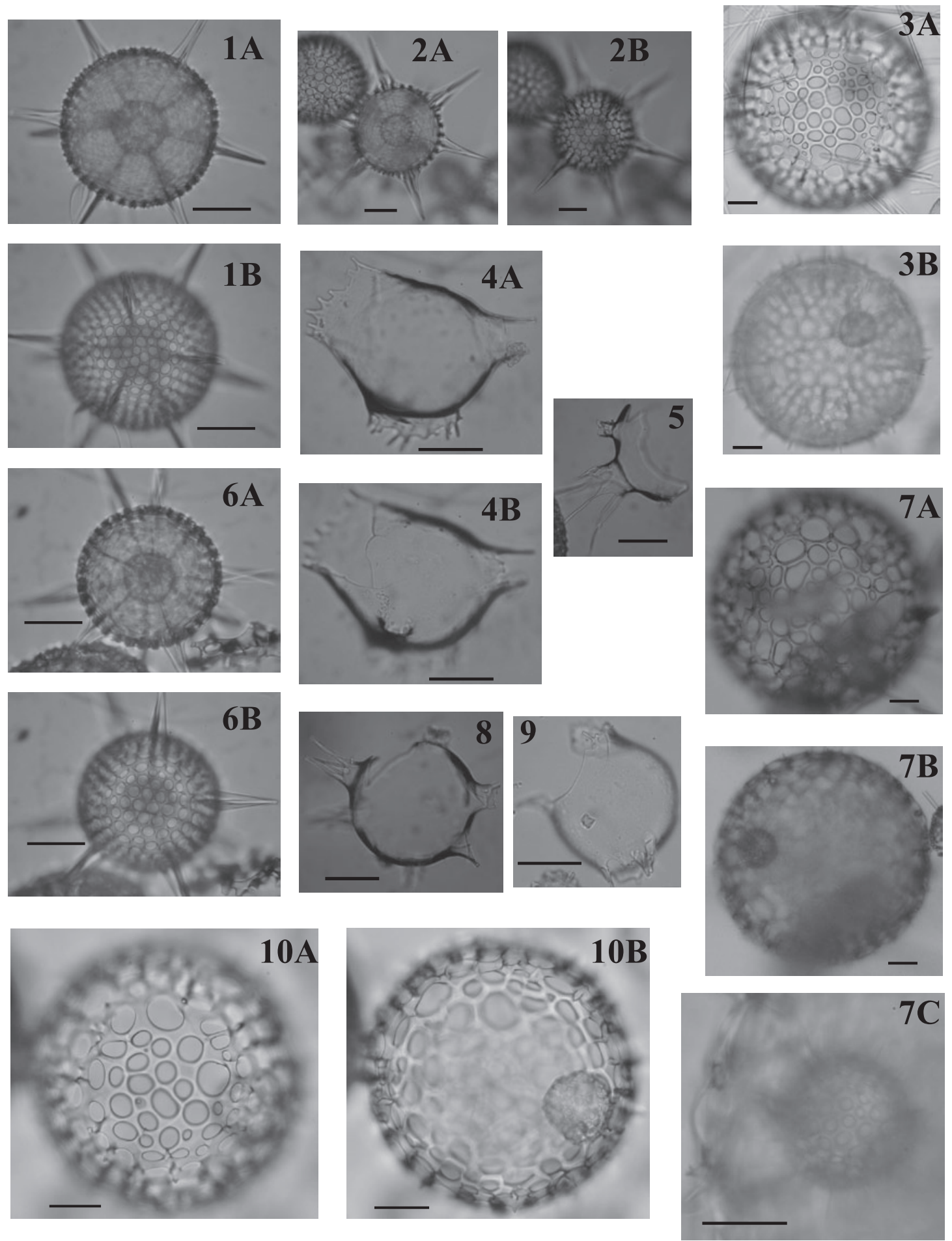

Explanation of Plate 2.

figs 1, 2, 6. Actinomma nigriniae n. sp.: 1A, focus on medullary shell; 1B, focus on cortical shell (both holotype, sample 120-751A-13H-2, 98/102 cm); 2A, focus on medullary shell; 2B, focus on cortical shell (both sample 120-748B-6H-4, 45/47 cm); 6A, focus on medullary shell; 6B, focus on cortical shell (both sample 120-748B-6H-5, 45/47 cm). figs 3, 7, 10. Carposphaera? annikae n. sp.: 3A, focus on cortical shell; 3B, focus on medullary shell (both sample 120-751A-11H-2, 98/102 cm); 7A, focus on cortical shell; 7B, focus on medullary shell; 7C, zoom on medullary shell (all holotype, sample 120-751A-7H-2, 98/102 cm); 10A, focus on cortical shell; 10B, focus on medullary shell (both sample 119-744A-4H-2, 59/61 cm). figs 4, 5, 8, 9. Siphonosphaera abelmannae $\mathrm{n}$. sp.: 4A, focus on a large tube; $\mathbf{4 B}$, focus on a small external tube (both holotype, sample 113-690B-6H-6, 22/24 cm); 5, 8, sample 120-748B-6H-5, 45/47 cm (5, fragment); 9, sample 119-744A$10 \mathrm{H}-1,60 / 62 \mathrm{~cm}$. Scale bars $50 \mu \mathrm{m}$. Magnification $\times 96$ on $7 \mathrm{~A}-\mathrm{B}, \times 192$ on $2 \mathrm{~A}-3 \mathrm{~B}$ and $10 \mathrm{~A}-\mathrm{B}, \times 384$ on $1 \mathrm{~A}-\mathrm{B}, 4 \mathrm{~A}-6 \mathrm{~B}, 8$ and 9 . 
Genus Carposphaera Haeckel, 1881

Type species. Carposphaera capillacea Haeckel, 1887

Carposphaera? annikae n. sp.

(P1. 2, figs 3A-B, 7A-C and 10A-B)

1887 ?Elatomma penicillus Haeckel: 243.

1991 ?Elatomma penicillus Haeckel; Takahashi: 69, pl. 9, figs $9-10$.

Derivation of name. After Annika Sanfilippo for her many contributions to radiolarian taxonomy and stratigraphy.

Diagnosis. Shell ratio of 1:4 to 1:6; inward-orientated, thin spines at each node of the cortical shell.

Holotype. Plate 2, figs 7A-C; sample 120-751A-7H-2 98/102 cm (Late Miocene); ECO-033.

Material. 83 specimens were observed from ODP Sites 690, 744, 747,748 and 751 .

Description. Very large, thick cortical shell with large, irregularly shaped, unequal, randomly distributed pores. On the inner side of the cortical shell, numerous small spines project inward at each node of the latticed shell. These projections are thin and slender; in rare specimens, they protrude on the outer side of the shell as relatively small, conical spines. A small medullary shell (4-6 times smaller than the cortical shell) is sometimes found free in the large cortical shell on unbroken specimens. Pores on this medullary shell are small, round and closely packed. The bars between the pores are crested and numerous thin spines project outwardly from each of the nodes.

The number and direction of the spines both on the medullary and on the cortical shell strongly suggest a connection between the two. The radial beams were probably too thin to be preserved.

Dimensions. Based on six specimens. Cortical shell diameter: $250-400 \mu \mathrm{m}(310 \mu \mathrm{m})$; medullary shell diameter: $60-75 \mu \mathrm{m}$ $(67 \mu \mathrm{m})$; cortical shell pore diameter: 6-43 $\mu \mathrm{m}(23 \mu \mathrm{m})$.

Occurrence. Sporadic from the $S$. radiosa to the A.golownini Zone (Early to Middle Miocene), rare from the middle A. golownini to the $S$. vesuvius Zone (Middle to Late Miocene) and fairly common from the $C$. spongothorax to the A. australis Zone (Late Miocene).

Remarks. Carposphaera? annikae differs primarily from Liosphaera antarctica Nakaseko, 1959 and the species of genus Carposphaera in its shell ratio and in the shape and size of its cortical shell pores. It also differs from other Actinommidae in its numerous thin radial beams. It finally differs from Elatomma penicillus in having larger elliptical pores, a thicker wall, a considerably smaller medullary shell (shell ratio of 1:4 to 1:6 instead of 1: 2 for E. penicillus) and in lacking branching radial spines.

Order Nassellaria Ehrenberg, 1876

Family Artostrobiidae Riedel, 1967, emend. Foreman, 1973 Genus Siphostichartus Nigrini, 1977
Type species. Cystophormis corona Haeckel, 1887

Siphostichartus jahnae n. sp.

(P1. 3, figs 6, 8A-11)

Derivation of name. After Regine Jahn for her efforts to preserve and restore the Ehrenberg Collection.

Diagnosis. Duck-billed vertical tube, long apical horn.

Holotype. Plate 3, figs 8A-B; sample 119-744A-5H-3 53/55 cm (Late Miocene); ECO-028.

Material. 229 specimens were observed from ODP Sites 744, 746, 748 and 751.

Description. Spindle-shaped four- to five-segmented shell.

The cephalis bears a duck-billed, upward-directed vertical tube and a long, slender apical horn (at least as long as cephalis but mostly as long as cephalothorax). This horn is very variable in shape: it can be straight, rod-like, blade-shaped, strongly curved or even bifurcated. The axobate is a cluster of several thin rods extending straight down toward the lumbar stricture. The pores on the thick cephalic wall are few, small and rounded.

Collar stricture is slightly indented dorsally. The pores on the thorax are bigger, rounded and arranged randomly. Lumbar stricture is marked by a strong indentation and a wide poreless area below. Abdomen is barrel-shaped or truncated-conical and bears four to six transverse rows of rounded to elliptical pores increasing in size distally (pores on the first row are smaller than the thoracic pores while pores in the final row are only slightly smaller than the pores on the fourth segment). The fourth segment is either barrel-shaped or inverted truncated-conical and bears four to five more or less regular transverse rows of large, transversallyelongated (elliptical to quadrangular) pores. When present, fifth segment is thinner, flares distally and bears irregular rows of irregularly-shaped (but mostly quadrangular) pores. The largest segment is invariably the fourth and the longest is either the abdomen or the fourth segment.

Dimensions. Based on seven specimens. Length of apical horn: 22-59 $\mu \mathrm{m}(35 \mu \mathrm{m})$; of vertical tube: 10-13 $\mu \mathrm{m}(12 \mu \mathrm{m})$; of cephalothorax: $36-42 \mu \mathrm{m}(40 \mu \mathrm{m})$; of third segment: $32-41 \mu \mathrm{m}$ (35 $\mu \mathrm{m})$; of fourth segment: $30-40 \mu \mathrm{m}(35 \mu \mathrm{m})$; of fifth segment: 16-41 $\mu \mathrm{m}(27 \mu \mathrm{m})$.

Occurrence. Rare from the A. golownini to the Tau Zone (Middle Miocene to Early Pliocene).

Remarks. Siphostichartus jahnae differs from S. corona and S. praecorona Nigrini, 1977 in its peculiar apical horn and in having a considerably shorter fourth segment. It also differs from Botryostrobus auritus-australis (Ehrenberg) group Nigrini, 1977 in the apical horn and in the post-thoracic segments that are, in B. auritus-australis, more or less uniform whereas, in $S$. jahnae, the segments that follow the thorax differ in width, length, shape, thickness (fifth segment) as well as in the shape of their pores. 


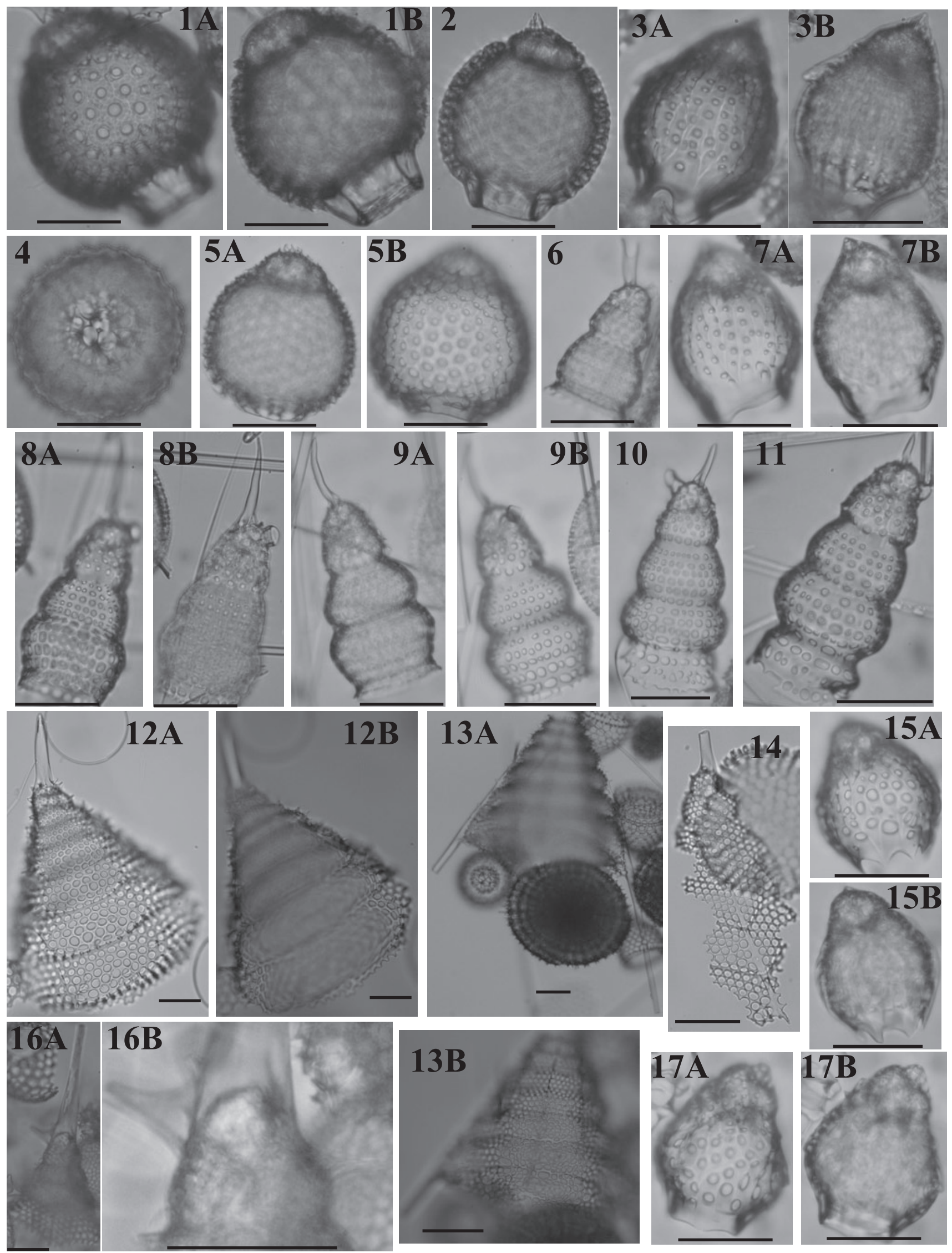


Genus Spirocyrtis Haeckel, 1881, emend. Nigrini, 1977

Type species. Spirocyrtis scalaris Haeckel, 1887

Spirocyrtis? hollisi n. sp.

(Pl. 3, figs 12A-14 and 16A-B)

1999a Cyrtida fam., genn. et spp. indet O’Connor: 500, pl. 4, fig. B. 2002 Spirocyrtis? aff. gyroscalaris Hollis: 301, pl. V, figs $7 \mathrm{a}-\mathrm{c}$.

Derivation of name. After Christopher J. Hollis, who first described this species.

Diagnosis. Strong apical horn; seven to eight segments with transverse pore rows; at least two strong ribs.

Holotype. Plate 3, figs 12A-B; sample 119-744A-5H-2 53/55 cm (Late Miocene); ECO-034.

Material. 18 specimens were observed from ODP Sites 690, 744, 747, 748 and 751 .

Description. Large conical shell with 7 or 8 segments.

Cephalis and thorax are separated only externally by shallow furrows. Apical horn is conical, long ( 2 to 3 times the length of the cephalothorax) and robust (c. as wide as cephalis). The cephalis also bears a triangular ventral horn (no vertical tube or vertical pore have been recognized though) and a dorsal horn (downwarddirected and smaller than the ventral one). Several small, additional horns are also present on both the cephalis and the thorax, and some specimens show small thorns on other segments as well. Pores on cephalis and thorax are small, numerous, closely packed, rounded to subhexagonal and loosely arranged in transverse rows.

The following segments (from the abdomen to the seventh segment) are barrel-shaped and expand distally both in width and in length (but considerably more in width than in length). The final segment (generally the eighth) tapers inwards (no specimen has a complete enough final segment to show the presence or absence of a mouth or any other feature). Pores on those segments are elliptical to hexagonal, arranged in transverse rows (3-6 per segment) and increase in size distally.

Two (?) strong ribs arise from the thoracic wall and continue as feet after the penultimate segment (generally the seventh). Some specimens show several weaker additional ribs.
Dimensions. Based on six specimens. Length of apical horn: 37$140 \mu \mathrm{m}(89 \mu \mathrm{m})$; of cephalothorax: $31-50 \mu \mathrm{m}(42 \mu \mathrm{m})$; of third segment: $15-33 \mu \mathrm{m}(25 \mu \mathrm{m})$. Only two specimens were found complete: total length $270 \mu \mathrm{m}$ and $310 \mu \mathrm{m}$; maximum width 250 $\mu \mathrm{m}$ and $270 \mu \mathrm{m}$.

Occurrence. Sporadic from the $S$. radiosa to the lower Chi Zone (Early Miocene to Early Pleistocene). This species has been reported by Hollis (2002) in Zone RP6 (Late Paleocene).

Remarks. The assignment of Spirocyrtis? hollisi to the genus Spirocyrtis is questionable since no vertical tube or vertical pore has been seen and no other Spirocyrtis (or no other Artostrobiidae) bear ribs. However, the structure of the cephalothorax, the alignment of the pores and the number of segments tend to indicate a close link between $S$.? hollisi and the other Spirocyrtis species $(S$. scalaris, S. subtilis Petrushevskaya in Petrushevskaya \& Kozlova, 1972, S. subscalaris Nigrini, 1977, S. gyroscalaris Nigrini, 1977, S. proboscis O'Connor, 1994 and S. greeni O'Connor, 1999b).

Family Cannobotryidae Haeckel, 1881, emend. Riedel, 1967 Genus Amphimelissa Jörgensen, 1905

Type species. Botryopyle setosa Cleve, 1899

Amphimelissa? hibernifortuna n. sp. (Pl. 6, figs 7-9)

Derivation of name. From the Latin, hibernus meaning 'the Irish' and fortuna meaning 'luck'; hibernifortuna, therefore, stands for 'the luck of the Irish', for its resemblance to a shamrock clover.

Diagnosis. Three cephalic chambers approximately spherical and equal in size, arranged triradiately instead of laterally.

Holotype. Plate 6, figs 8A-B; sample 119-744A-4H-2 59/61 cm (Late Miocene); ECO-037, circle 1.

Material. 134 specimens were observed from ODP Sites 737, 744, 746, 747, 748 and 751.

Description. Small, two-segmented shell with rough, crested, thorny surface. The thorax is cylindrical, short - approximately equal in length and width to the cephalis. Its termination is ragged. Thoracic pores are rounded, unequal in size and distributed randomly.

\section{Explanation of Plate 3.}

figs 1, 2, 4, 5. Cystophormis gargantua n. sp.: 1A, focus on shell surface; 1B, focus on internal structure (sample 120-748B-6H-1, 45/47 $\mathrm{cm}) ; 2$, holotype, specimen with apical horn (sample 120-748B-6H-3, 45/47 cm); 4, specimen seen from below, focus on collar pores (sample 120-748B-6H-1, 45/47 cm); 5A, focus on shell surface; 5B, focus on internal structure (sample 119-744A-11H-3, 45/47 cm). figs 3, 7, 15, 17. Carpocanium? uburex n. sp.: 3A, focus on thorax; 3B, focus on cephalis (sample 119-738B-1H-3, 53/55 cm); 7A, holotype, focus on thorax; $\mathbf{7 B}$, holotype, focus on cephalis; $\mathbf{1 5 A}$, focus on shell surface; $\mathbf{1 5 B}$, focus on internal structure; $\mathbf{1 7 A}$, focus on shell surface; 17B, focus on internal structure (figs 7, 15, 17 sample 120-747A-2H-2, 45/47 cm). figs 6, 8-11. Siphostichartus jahnae n. sp.: 6, specimen with bifurcated apical spine (sample 120-751A-12H-3, 98/102 cm); 8A, holotype, focus on post-thoracic segments; 8B, holotype, focus on cephalis inner structure (sample 119-744A-5H-3, 53/55 cm); 9A, focus on apical horn; 9B, focus on shell surface (sample 120-751A-11H4, 98/102 cm); 10, sample 120-751A-12H-1, 98/102 cm; 11, sample 120-748B-5H-5, $45 / 47$ cm. figs 12-14, 16. Spirocyrtis? hollisi n. sp.: 12A, holotype, focus on shell wall; 12B, holotype, focus on rib (sample 119-744A-5H-2, 53/55 cm); 13, specimen with broken cephalis (sample 120-748B-6H-2, 45/47 cm) - A focus on contour, B focus on shell wall; 14, fragment (sample 120-748B-6H-1, 45/47 cm); 16, broken specimen (sample 119-744A-8H-2, 60/62 cm) - A focus on contour, B zoom on cephalis. Scale bars $50 \mu \mathrm{m}$. Magnification $\times 384$ on $1 \mathrm{~A}-11 ; \times 192$ on $12 \mathrm{~A}-\mathrm{B}, 13 \mathrm{~B}, 14$ and $16 \mathrm{~A} ; \times 96$ on $13 \mathrm{~A} ; \times 960$ on $16 \mathrm{~B}$. 

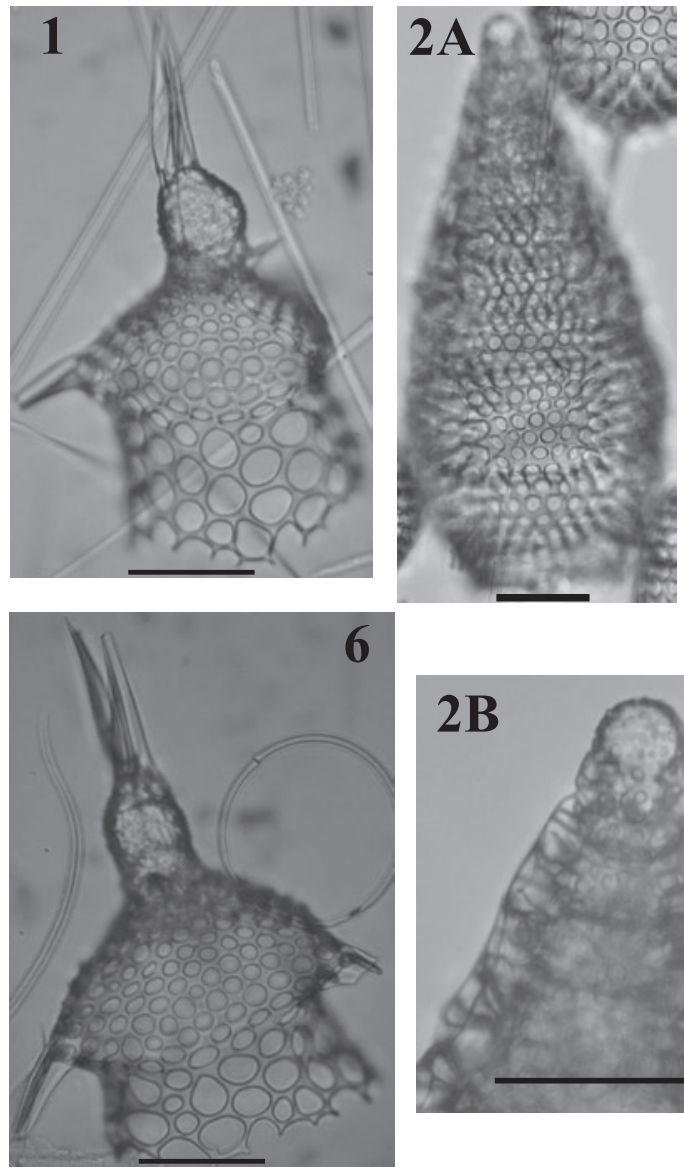

(
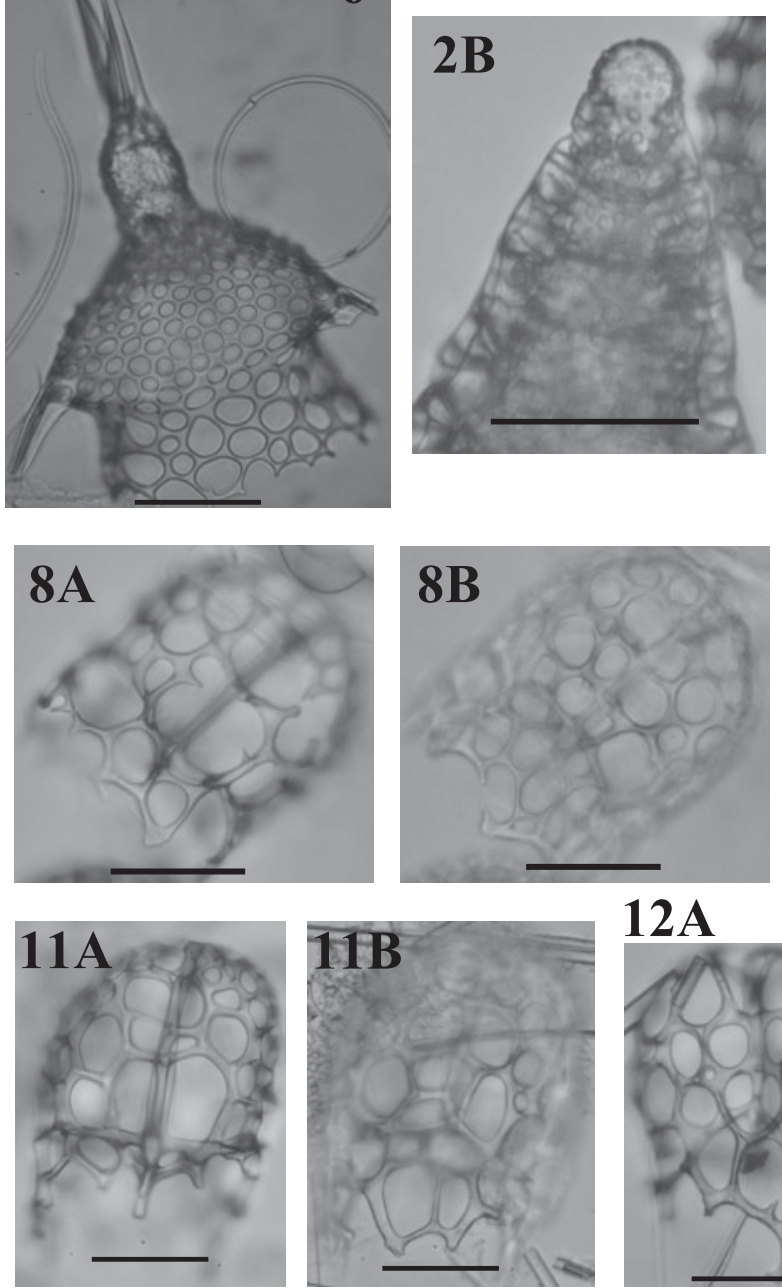
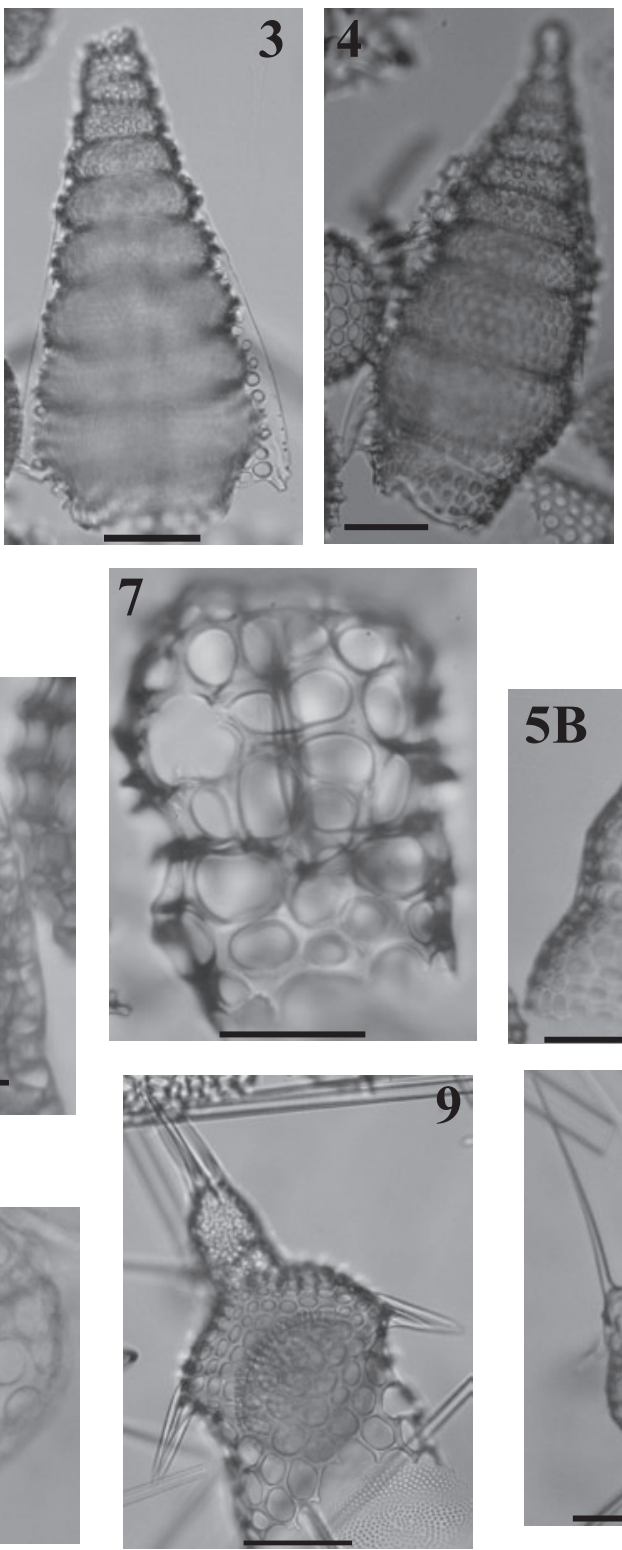

12B

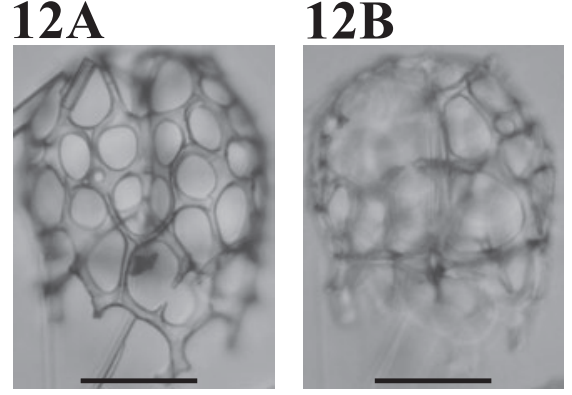

\section{Explanation of Plate 4.}

figs 1, 6, 9. Gondwanaria clarae n. sp.: 1, holotype (sample 120-748B-5H-5, 45/47 cm); 6, sample 120-751A-12H-2, 98/102 cm; 9, sample 120-751A-10H-2, 98/102 cm. figs 2, 3, 4. Stichophormis? cheni n. sp.: 2A, holotype, focus on shell wall; 2B, holotype, zoom on cephalis (sample 119-744A-8H-1, 60/62 cm); 3, specimen with broken cephalis (sample 120-751A-15H-CC); 4, sample 120-751A-16H-CC. figs 5, 10, 13. Artostrobus semazen n. sp.: 5A, holotype, whole specimen; 5B, focus on cephalis (sample 120-748B-5H-7, 45/47 cm); 10, 13, sample 120-751A-6H-6, 98/102 cm. figs 7, 8, 11, 12. Dendrospyris? jobstae n. sp.: 7, holotype; 8A, front; 8B, back (sample 120-747A3H-5, 45/47 cm); 11A, front; 11B, back (both figs 7 and 11, sample 119-745B-14H-6, 53/55 cm); 12A, back; 12B, front (sample 120747A-3H-5, 45/47 cm). Scale bars $50 \mu \mathrm{m}$. Magnification $\times 384$ on all except on $2 \mathrm{~A}, 3,4,5 \mathrm{~A}$ and $9(\times 192)$. 

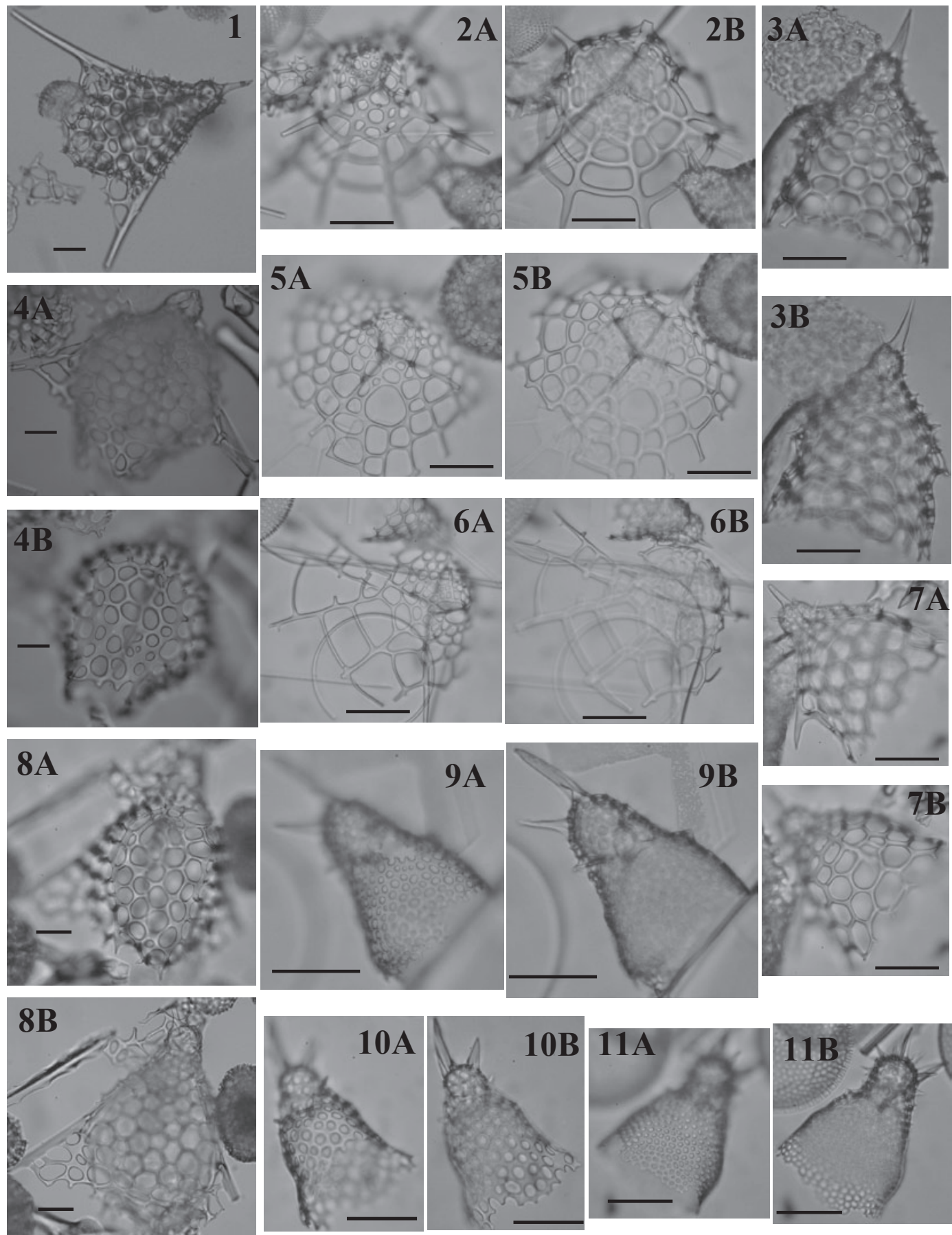

Explanation of Plate 5 .

figs 1, 4, 8. Dictyophimus larus n. sp.: 1, holotype (sample 120-748B-6H-1, 45/47 cm); 4A, focus on cephalis; 4B, focus on thorax (sample 120-7474-10H-4, 45/47 cm); 8A, focus on thorax; 8B, focus on cephalis (sample 119-744A-8H-3, 53/55 cm). figs 2, 5, 6. Ceratocyrtis dolvenae n. sp.: 2A, focus on cephalis wall; 2B, focus on cephalis inner structure (sample 120-751A-3H-4, 98/102 cm); $\mathbf{5 A}$, holotype, focus on cephalis wall; 5B, holotype, focus on cephalis inner structure (sample 120-748B-6H-3, 45/47 cm); 6A, focus on cephalis wall; 6B, focus on cephalis inner structure (sample 120-751A-7H-2, 98/102 cm). figs 3, 7. Dictyophimus? kiwi n. sp.: 3A, holotype, focus on thorax wall; 3B, holotype, focus on apical horn (sample 120-748B-6H-1, 45/47 cm); 7A, focus on apical horn; 7B, focus on thorax wall (sample 120-748B-6H-4, 45/47 cm). figs 9, 10, 11. Lophophaena leberu n. sp.: 9A, holotype, focus on thorax wall; 9B, holotype, focus on cephalis inner structure (sample 120-748B-7H-2, 45/47 cm); 10, specimen with larger pores (sample 120-751A-16H-CC) - A focus on thorax wall, B focus on cephalis inner structure; 11, specimen with numerous additional horns (sample 120-751A-18H-CC) - A focus on thorax wall; B focus on cephalis inner structure. Scale bars $50 \mu$ m. Magnification $\times 96$ on 1 , $\times 192$ on $4 \mathrm{~A}-\mathrm{B}$ and $8 \mathrm{~A}-\mathrm{B}, \times 384$ on $2 \mathrm{~A}-3 \mathrm{~B}, 5 \mathrm{~A}-7 \mathrm{~B}$ and $9 \mathrm{~A}-11 \mathrm{~B}$. 

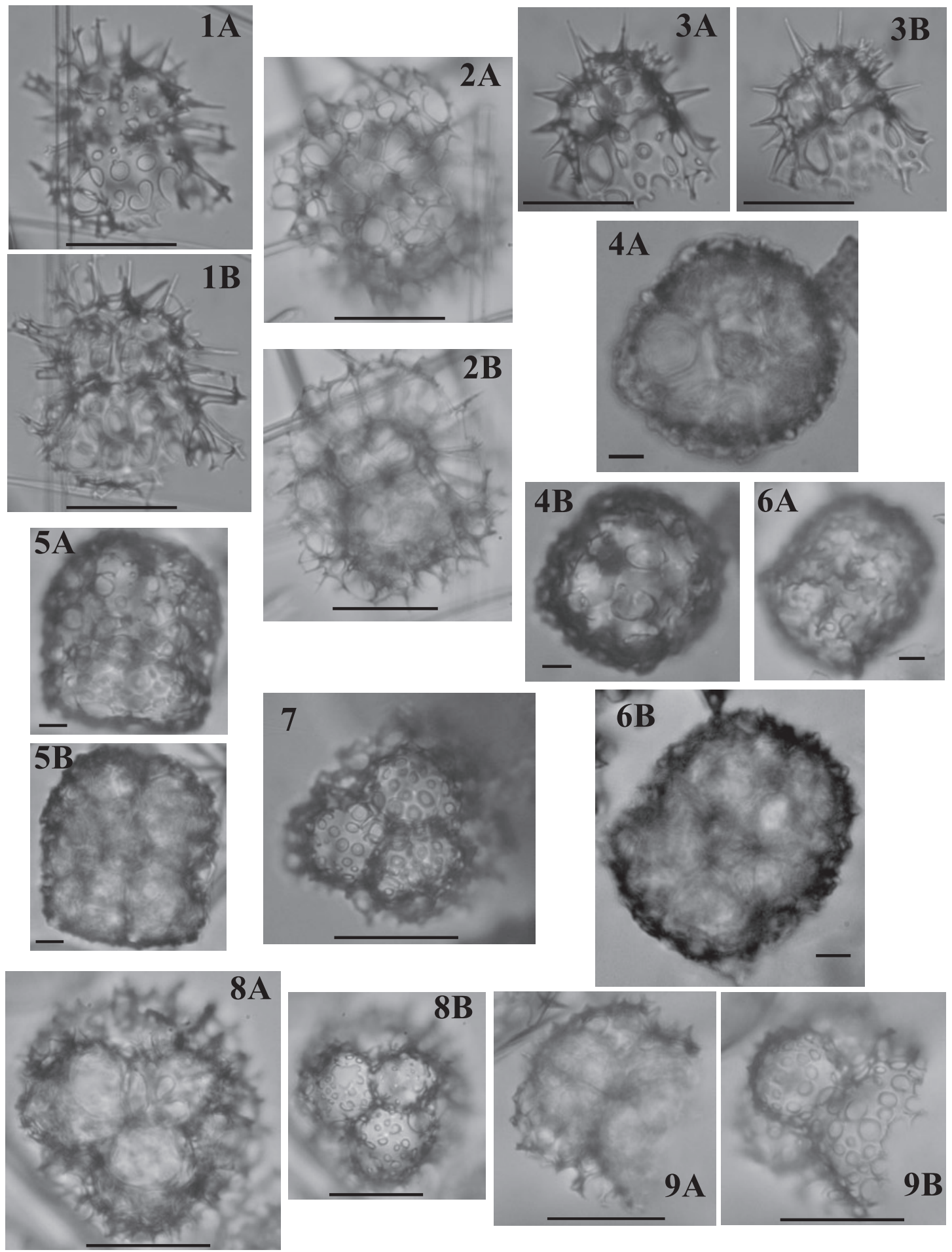

\section{Explanation of Plate 6.}

figs 1, 2, 3. Syscioscenium? wabisabi n. sp.: 1A, holotype, focus on shell wall; 1B, holotype, focus on inner structure (sample 120-751A7H-4, 98/102 cm); 2A, focus on secondary meshwork; 2B, focus on inner structure (sample 120-751A-9H-5, 98/102 cm); 3A, focus on shell wall; 3B, focus on inner structure (sample 119-746A-7H-6, 53/55 cm). figs 4-6. Antarctissa ballista n. sp.: 4A. apical view, focus on shell wall; 4B, apical view, focus on ring structure (sample 119-746B-8H-CC, 20/22 cm); $5 \mathbf{A}$, focus on shell wall; $5 \mathbf{B}$, focus on ring structure (sample 119-746B-8H-1, 53/55 cm); 6A, holotype, focus on shell wall; 6B, focus on ring structure (sample 120-751A-6H-1, 98/102 cm). figs 7-9. Amphimelissa? hibernifortuna n. sp.: 7, apical view (sample 119-746A-13X-2, 53/55 cm); 8A, holotype, apical view, focus on inner structure; 8B, holotype, apical view, focus on shell wall; 9A, focus on inner structure; 9B, focus on shell wall (both figs 8 and 9, sample 119-744A-4H-2, 59/61 cm). Scale bars $50 \mu \mathrm{m}$ on $1 \mathrm{~A}-3 \mathrm{~B}$ and $7-9 \mathrm{~B}$ and $10 \mu \mathrm{m}$ on $4 \mathrm{~A}-6 \mathrm{~B}$. Magnification $\times 384$. 
The cephalis is trilobate with two chambers equal in size and a eucephalic lobe somewhat smaller. The three lobes are spherical and are arranged triradiately around spine A (see Pl. 6, fig. 9A). Cephalic pores are small and sparser than the thoracic ones. The internal spines do not seem to protrude outside the cephalic wall with the notable exception of spine A, which can continue as a small, thornlike spine. In apical view (see Pl. 6, fig. 8A; cf. Petrushevskaya, 1971, pl. 10, fig. 8), eucephalic chamber inner structure can be seen: spine $\mathrm{V}$ crosses the eucephalic chamber longitudinally while two wide, flat arches pj - according to Petrushevskaya's (1971) terminology - join spines $\mathrm{V}$ and $\mathrm{L}$. The two other cephalic chambers are separated by spine D: therefore, it is not an antecephalic and postcephalic chamber but an antecephalic chamber split into two lobes.

Dimensions. Based on four specimens in apical view. Thorax maximum width: 64-100 $\mu \mathrm{m}(80 \mu \mathrm{m})$; cephalic chamber diameter: $29-44 \mu \mathrm{m}(35 \mu \mathrm{m})$.

Occurrence. Rare from the C. humerus to the Tau Zone (Middle Miocene to Early Pliocene).

Remarks. The cephalic lobe arrangement seems to be unique to this species amongst other Cannobotryidae. Because of this peculiar layout, where the three lobes are not ante-, eu- and postcephalic but rather an eucephalic and two antecephalic lobes, the affinity with the genus Amphimelissa remains putative.

Family Carpocaniidae Haeckel, 1881, emend. Riedel, 1967 Genus Cystophormis Haeckel, 1887

Type species. Cystophormis pyla Haeckel, 1887

Cystophormis gargantua $\mathrm{n}$. sp.

(P1. 3, figs $1 \mathrm{~A}-\mathrm{B}, 2,4$ and $5 \mathrm{~A}-\mathrm{B})$

1992 ?Carpocanistrum spp. Sugiyama et al.: pl. 27, fig. 8 (non figs 7 and 9).

Derivation of name. After the giant Gargantua in Rabelais' eponymous novel.

Diagnosis. Large (c. $130 \mu \mathrm{m}$ long and c. $110 \mu \mathrm{m}$ wide) Carpocaniid with a short trilobate cephalis.

Holotype. Plate 3, fig. 2; sample 120-748B-6H-3 45/47 cm (Early Miocene); ECO-048, circle 1.

Material. 846 specimens were observed from ODP Sites 690, 744 and 748 .

Description. Large two-segmented shell with a trilobate domeshaped cephalis and a barrel-shaped to spherical thorax ending with a wide hyaline peristome of variable length.

The three lobes of the cephalis are not marked externally. The eucephalic lobe is slightly wider and taller than the two others. In some specimens, a small tribladed apical spine arises at the junction between the eucephalic and the antecephalic lobe. Externally, the collar stricture is marked by an indentation and, in some specimens, by a slight change in contour. Internally, the cephalis and the thorax are marked by a plate pierced by four adjacent collar pores (two large and two small). The cephalic wall is thick, crested and bears only a few, small, rounded pores.

The thoracic wall is also thick and crested. It bears larger, round pores that are aligned longitudinally (on half the equator, 8-11 rows of $7-10$ pores). Transversally, they are arranged according to a hexagonal pattern. Because of the crests on the wall, each pore seems to be framed. The longitudinal alignment is not strict: it particularly tends to be irregular near the peristome.

The peristome is thick, smooth and hyaline, internally cylindrical and externally cylindrical to inverted truncated-conical. The pore frames of the pores closest to the peristome sometimes extend to its base.

Dimensions. Based on six specimens. Total length: 109-140 $\mu \mathrm{m}$ (128 $\mu \mathrm{m})$; maximum width: 93-121 $\mu \mathrm{m}(111 \mu \mathrm{m})$; length of cephalis: $16-25 \mu \mathrm{m}(20 \mu \mathrm{m})$; of thorax: $77-95 \mu \mathrm{m}(87 \mu \mathrm{m})$.

Occurrence. Common from the $S$. radiosa to the E. punctatum Zone (Early to Middle Miocene).

Remarks. Cystophormis gargantua differs from other carpocaniids primarily in its size. It also differs from Sethocorys odysseus Haeckel, 1887 in its cephalis being flat and distinctly trilobed, and in the collar stricture being less marked; from Carpocanopsis favosa (Haeckel) 1887 in the peristome being cylindrical or inverted conical rather than widening distally and in having a smooth termination.

Genus Carpocanium Ehrenberg, 1847

Type species. Lithocampe solitaria Ehrenberg, 1844a

Carpocanium? uburex n. sp.

$$
\text { (P1. 3, figs 3A-B, 7A-B, 15A-B and 17A-B) }
$$

Derivation of name. After Alfred Jarry's play 'King Ubu', for the resemblance of the specimen on Plate 3, fig. 17A-B with the eponymous character.

Diagnosis. Spindle-shaped shell; large cephalis; large peristomial teeth.

Holotype. Plate 3, figs 7A-B; sample 120-747A-2H-2 45/47 cm (Pleistocene); ECO-038.

Material. 41 specimens were observed from ODP Sites 738, 744, 747 and 751.

Description. Spindle-shaped two-segmented shell. Cephalis is wide and separated externally into three lobes by a more or less pronounced furrow near spine A and another near spine V(?). Spine A is free in the cephalis and often continues outside as a small, tribladed apical horn. Post-cephalic lobe seems on some specimens to open on a vertical tube. The axobate was not observed.

The collar stricture is marked outside by a furrow and a more or less pronounced shoulder. Some specimens bear a small triangular wing as a continuation of spine D. Cephalic wall is crested and bears a few small, rounded, unevenly distributed pores. Pores on the thoracic wall, however, are bigger (but of variable size), often elongated in the longitudinal direction and somewhat aligned longitudinally. This alignment is not strict and tends to be very irregular 
near the peristome. Ridges can be seen in most specimens between the longitudinal row; they follow the irregularity of the pore alignment. The peristome is hyaline and is composed of a variable number of inward-orientated teeth. The teeth can be either shovel-shaped or triangular or simply a wavy aperture. There is rarely a change in contour between the thorax and the peristome.

Dimensions. Based on five specimens. Total length: 92-105 $\mu \mathrm{m}$ (99 $\mu \mathrm{m})$; maximum width: $69-76 \mu \mathrm{m}(72 \mu \mathrm{m})$; length of cephalis: 15-27 $\mu \mathrm{m}(22 \mu \mathrm{m})$; of thorax: 60-75 $\mathrm{mm}(65 \mu \mathrm{m})$.

Occurrence. Rare from the Phi to the Psi Zone (Pleistocene).

Remarks. Carpocanium? uburex differs from Plannapus microcephalus (Haeckel) 1887, P. papillosus (Ehrenberg) 1872, P. mauricei O'Connor, 1999 and $P$. hornibrooki O'Connor, 1999 in the presence of large teeth around the peristome, its cephalis/thorax ratio and the presence of ridges. It also differs from Carpocanium kinugasense Nishimura, 1990 in the cephalis being clearly separated externally from the thorax and in the inner structure of the cephalis; and from Carpocanium rubyae O'Connor, 1997 for the same reasons as the latter and in the pore alignment being far more irregular in C.? uburex. As the ventral tube present in the species of genus Plannapus was not clearly observed here, C.? uburex was assigned to genus Carpocanium even though it shares many other characteristics with the four Plannapus species cited above.

Family Collosphaeridae Müller, 1858

Genus Acrosphaera Haeckel, 1881

Type species. Acrosphaera echinoides Haeckel, 1887

Acrosphaera cuniculiauris n. sp.

(Pl. 7, figs 1A-B, 2 and 13)

1979 Cenosphaera sp. Chen; Keany: 51, pl. 1, fig. 3, pl. 5, fig. 1; non Cenosphaera sp. Chen, 1975, p. 453, pl. 6, fig. 9; pl. 7, figs $1-2$.

2002 Cenosphaera sp. Keany; Vigour \& Lazarus: 4, pl. P1, figs 4-13.

Derivation of name. cuniculus is Latin for bunny and auris for ears; therefore, cuniculiauris stands for bunny ears, for the shape of the lamellar projections.
Diagnosis. Large pores surrounded by up to three forked lamellar projections.

Holotype. Plate 7, figs 1A-B; sample 120-747A-4H-3 45/47 cm (Late Miocene/Early Pliocene); ECO-047.

Material. 133 specimens (including identifiable fragments and broken specimens) were observed from ODP Sites 747 and 751.

Description. Large latticed sphere made of thin lamellar bars separating large subcircular pores. Each pore bears, at its margin, up to three appendices. Those projections are lamellar, of the same width as the bars of the latticed shell, and bi- or trifurcate distally. There are a few smaller pores between the large ones, but those do not bear appendices.

Dimensions. Based on four specimens. Pore diameter: 34-63 $\mu \mathrm{m}$ $(50 \mu \mathrm{m})$; bar width: $8-18 \mu \mathrm{m}(12 \mu \mathrm{m})$.

Occurrence. Rare to common from the A. australis to the $A$. challengerae Zone (Late Miocene), appears mostly as fragments.

Remarks. Acrosphaera cuniculiauris differs from A. murrayana (Haeckel) 1887 primarily in the width of the pores and the appendages surrounding them being several forked lamellar projections instead of one single tubular projection. It also differs from A. trepanata (Haeckel) 1887, as illustrated by Goll (1980), in the shape of the appendages and the absence of a rim around the apertures.

Genus Siphonosphaera Müller, 1858

Type species. Collosphaera tubulosa? Müller, 1855

Siphonosphaera abelmannae n. sp. (P1. 2, figs 4A-B, 5, 8 and 9)

1990 Disolenia spp. group Abelmann: 690, pl. 1, figs 3A-B.

Derivation of name. After Andrea Abelmann, who first illustrated this species.

Diagnosis. Poreless sphere; a few external tubes ending irregularly.

Holotype. Plate 2, figs 4A-B; sample 113-690B-6H-6 22/24 cm (Early Miocene); ECO-046.

Explanation of Plate 7.

figs 1, 2, 13. Acrosphaera cuniculiauris n. sp.: 1A, holotype, focus on shell surface; 1B, holotype, focus on lamellar projections (sample 120-747A-4H-3, 45/47 cm); 2, fragment; 13, fragment with poorly developed projections (both figs 2 and 13, sample 120-751A-5H-5, 98/102 cm). figs 3-6. Botryopera? gibbera n. sp.: 3A, holotype, focus on shell surface; 3B, holotype, focus on internal structure (sample 120-751A-10H-4, 98/102 cm); 4A, focus on shell surface; 4B, focus on internal structure (sample 119-744A-6H-4, 60/62 cm); 5A, focus on shell surface; 5B, focus on internal structure (sample 120-751A-6H-3, 98/102 cm); 6A, focus on shell surface; 6B, focus on internal structure (sample 120-751A-9H-6, 98/102 cm). figs 7, 9, 10. Lithomelissa vespa $\mathrm{n}$. sp.: 7A, holotype, focus on shell surface; 7B, holotype, focus on internal structure (sample 119-744A-4H-2, 56/61 cm); 9A, focus on shell surface; 9B, zoom on internal structure (sample 120751A-6H-6, 98/102 cm); 10, specimen with thin shell (sample 120-751A-9H-6, 98/102 cm). figs 8, 11, 12. Trisulcus pinguiculus n. sp.: 8, two specimens, one seen from above (holotype), the other sideways (sample 120-748B-8H-6, 45/47 cm) - A focus on internal structure, $\mathbf{B}$ focus on shell surface; 11, specimen with long thorax (sample 120-748B-8H-4, 45/47 cm) - A focus on shell surface; B focus on internal structure; 12A, focus on shell surface; 12B, focus on internal structure (sample 120-748B-8H-4, $45 / 47 \mathrm{~cm}$ ). Scale bars $50 \mu \mathrm{m}$ except on $9 \mathrm{~B}$, where it is $10 \mu \mathrm{m}$. Magnification $\times 384$ except on $1 \mathrm{~A}-\mathrm{B}(\times 96)$ and on $9 \mathrm{~B}(\times 960)$. 

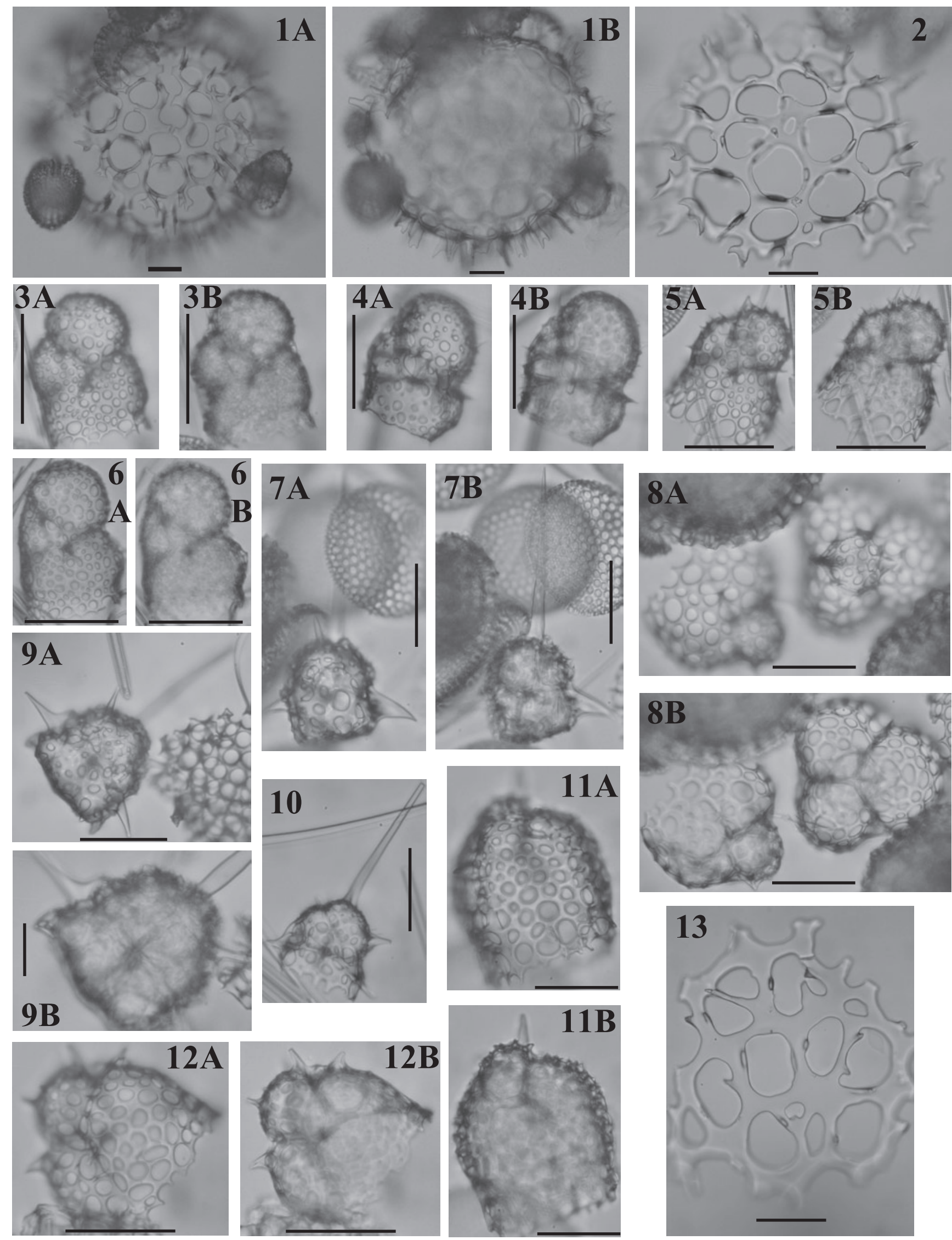
Material. 37 specimens were observed from ODP Sites 690, 744, 748 and 751.

Description. Small, smooth, hyaline sphere with two to seven large external tubes of variable diameter. Each tube is generally subcylindrical and as long as the diameter of the aperture. These tubes end with thin, irregularly shaped, filamentous appendices which can be twice as long as the tube itself.

Dimensions. Based on nine specimens. Shell diameter: 84-125 $\mu \mathrm{m}(107 \mu \mathrm{m})$; tube diameter: $21-80 \mu \mathrm{m}(40 \mu \mathrm{m})$.

Occurrence. Rare from the $S$. radiosa to the $C$. golli regipileus Zone (Early Miocene).

Remarks. Siphonosphaera abelmannae differs from A. murrayana in having fewer apertures and in being considerably smaller (its diameter is approximately three times smaller). It also differs from species of the genus Trisolenia in having a poreless, hyaline wall; from S. hyalina Caulet, 1986 in having more numerous, larger tubes; from $S$. chonopora Haeckel, 1887 in the tubes widely expanding distally in the latter; and from the subspecies $S$. socialis Haeckel, 1887 tubuliloba Strelkov \& Reshetnjak, 1971 in the shell being totally poreless and lacking crests and in the tubes being larger.

Family Theoperidae Haeckel, 1887, emend. Riedel, 1967 Genus Artostrobus Haeckel, 1887

Type species. Cornutella annulata Bailey, 1856

Artostrobus semazen n. sp.

(Pl. 4, figs 5A-B, 10 and 13)

Derivation of name. semazen is Turkish for a 'Whirling Dervish'.

Diagnosis. Long apical horn; mid-thorax constriction; lower thorax flares distally; pores aligned in transverse rows.

Holotype. Plate 4, figs 5A-B; sample 120-748B-5H-7 45/47 cm (Middle Miocene); ECO-045.

Material. 11 specimens were observed from ODP Sites 748 and 751.

Description. Two-segmented shell with a small hemispherical cephalis and a thorax divided into an upper and a lower thorax by a change in contour at mid-height and a slight constriction.

Cephalis has a poreless wall. Spine A runs in the cephalic wall as a rib from the collar stricture to the apex where it continues outside as a long (generally as long as the whole shell but can be longer), slender conical horn. Spines D, Ll and Lr protrude outside the cephalic wall at the collar stricture at first as ribs on the uppermost part of the thorax and then as curved, downward-directed, thin, slender wings. Spine $\mathrm{V}$ also continues as a short, thin and slender horn that forms a $c .50^{\circ}$ angle with the apical horn. Arches $\mathrm{AL}$ form small ribs on the cephalic wall (see Pl. 4, fig. 10). A small axobate can be seen at the junction between spines V, Ll and Lr.

The upper thorax is somewhat barrel-shaped, whereas the lower thorax forms a short flaring skirt. Both have thin, smooth walls with transverse rows of circular to hexagonal or quadrangular pores. Some of these pores are infilled on the uppermost part of the thorax. Some specimens shows a differentiation in the size of the upper and lower thorax pores; but, most generally, pores are approximately even in size.

Dimensions. Based on four specimens. Shell length (without horn): 54-70 $\mu \mathrm{m}(61 \mu \mathrm{m})$; apical horn length: 54-226 $\mu \mathrm{m}(68$ $\mu \mathrm{m})$; lower thorax maximum width: $45-50 \mu \mathrm{m}(48 \mu \mathrm{m})$; width at constriction: $33-37 \mu \mathrm{m}(35 \mu \mathrm{m})$.

Occurrence. Sporadic to rare from the lower C. spongothorax to the $A$. australis Zone (Middle to Late Miocene).

Remarks. Artostrobus semazen differs from A. annulatus, A. joergenseni Petrushveskaya, 1967, A. quadriporus Bjørklund, 1976a and A.? pretabulatus Petrushevskaya, 1975 in its thorax being differentiated into an upper thorax and a flaring lower thorax. It also differs from Cycladophora davisiana Ehrenberg, 1872, C. conica Lombari \& Lazarus, 1988, C. cosma Lombari \& Lazarus, 1988 and C. robusta Lombari \& Lazarus, 1988 in its pore size and disposition, in the constriction and change in contour between the upper and lower thorax, in the apical and ventral horns being slender and conical and in the presence of dorsal and lateral wings.

Genus Dictyophimus Ehrenberg, 1847 sensu Nigrini, 1967

Type species. Dictyophimus crisiae Ehrenberg, 1854

Dictyophimus larus n. sp.

(Pl. 5, figs 1, 4A-B and 8A-B)

1975 Pterocanium sp. Benson; Chen: 13, fig. 9.

1992 Pterocanium(?) sp Takemura: 747, pl. 1, fig. 7.

Derivation of name. larus is Latin for a seagull.

Diagnosis. Large pyriform thorax; wings widely flaring; rough, thick cephalis.

Holotype. Plate 5, fig. 1; sample 120-748B-6H-1 45/47 cm (Early Miocene); ECO-040.

Material. 22 specimens were observed from ODP Sites 744, 747 and 748 .

Description. Two-segmented shell with a small, spherical cephalis and a very large pyriform thorax.

The cephalis is thick, rough, bumpy and poreless. It bears a conical, fairly long horn in relation with spine A, which is free in the cephalic cavity. The cephalis also bears many thorns that could be almost as long as the apical horn. Spines D, Ll and Lr continue in the thoracic wall as thick, cylindrical ribs that protrude at midlength outside the wall as long, widely (up to $80^{\circ}$ ) flaring wings.

Pores on thorax are large, unequal in size, circular to polygonal. The bars between the pores are relatively thin (compared to the pores), slightly crested and they bear spine-like thorns on the upper thorax at each node. At mid-length the thorax begins to taper inwards, to the closure which is a large peristome with the same lattice wall as the rest of the thorax. Bars often connect the wings with the upper part of this peristome. 
Dimensions. Based on four specimens. Length (without the horns): 199-288 $\mu \mathrm{m}(247 \mu \mathrm{m})$; maximum width: 134-220 $\mu \mathrm{m}$ (180 $\mu \mathrm{m})$; wing length: 244-345 $\mu \mathrm{m}(290 \mu \mathrm{m})$.

Occurrence. Very rare from the $S$. radiosa to the E. punctatum Zone (Early to Middle Miocene). According to Takemura (1992), this species originates in the Eocene or earlier.

Remarks. Dictyophimus larus differs primarily from the other Pterocanids in its size. It also differs from $D$. crisiae, $D$. hirundo (Haeckel) 1887 and D. infabricatus Nigrini, 1968 in its thick, rough, thorn-bearing cephalis. The thorax termination seems to be also typical of this species.

\section{Dictyophimus? kiwi n. sp. \\ (Pl. 5, figs 3A-B and 7A-B)}

Derivation of name. After the kiwi bird.

Diagnosis. Short wings; large flaring thorax.

Holotype. Plate 5, figs 3A-B; sample 120-748B-6H-1 45/47cm (Early Miocene); ECO-043.

Material. 23 specimens were observed from ODP Sites 744, 748 and 751 .

Description. Two-segmented shell with a small spherical cephalis and a large, long, flaring thorax.

The cephalis bears several, scattered, very small circular pores, together with a long (almost twice the length of the cephalis), conical apical horn, a small and thin ventral horn and several additional thin and short horns, unconnected to any internal spines. Spine A and V are free in the cephalic cavity. Spines D, Ll and Lr extend as thin, cylindrical ribs on the upper part of the thorax and end up protruding outside the thoracic wall as very short and thin conical wings.

The thoracic pores are polygonal and get bigger along a gradient from the cephalis to the flaring termination of the thorax. The angle formed by the lower thorax (i.e. the part below the wings) is somewhat smaller than the angle formed by the upper thorax. The thin bars between the upper thoracic pores are crested and often bear thorns.

Dimensions. Based on three specimens. Length (without the horns): 123-148 $\mu \mathrm{m}(138 \mu \mathrm{m})$; maximum width: 110-126 $\mu \mathrm{m}(120 \mu \mathrm{m})$.

Occurrence. Very rare from the $C$. antiqua to the A. golownini Zone (Early to Middle Miocene).

Remarks. Dictyophimus? kiwi differs from the other species of the genus Dictyophimus in its short wings and its long thorax extending well below the wings.

\section{Genus Gondwanaria Petrushevskaya, 1975}

Type species. Lithomelissa campanulaeformis Campbell \& Clark, 1944 (=Sethoconus dogieli Petrushevskaya, 1967)

Gondwanaria clarae n. sp.

(Pl. 4, figs 1, 6 and 9)
Derivation of name. After Clara Ehrenberg who devoted much of her life to supporting the study of radiolaria and other micro-organisms.

Diagnosis. Apically elongated cephalis with a strong lanceolate apical horn; three strong tribladed wings; median constriction of the thorax.

Holotype. Plate 4, fig. 1; sample 120-748B-5H-5 45/47 cm (Middle Miocene); ECO-044.

Material. 104 specimens were observed from ODP Sites 737, 744,748 and 751.

Description. Two-segmented shell with a narrow, apically elongated, ellipsoidal (almost twice as long as wide in some specimens) cephalis and a large (at least three times the width of the cephalis) thorax with a conical, quickly flaring, upper thorax with three long, tribladed wings and a broadly cylindrical lower thorax.

The cephalis and the thorax are separated by a marked collar stricture. The cephalis is rough, crested and poreless. It bears a strong, lanceolated, tribladed, apical horn (up to twice the length of the cephalis) at the apex and a short, tribladed, ventral horn at the collar stricture, directed slightly upward.

Spine A is free in the cephalic cavity. Arches AL are clearly seen at approximately the first quarter of the length of the cephalis and appear parallel to MB; they are not, however, expressed externally by any furrows or strictures. Spines D, Ll and Lr protrude outside the upper thorax wall as three long (as long as the apical horn), tribladed spines.

The upper and the lower thorax are separated by a superficial constriction below the wings. The pores on the upper thorax are rather small and increase in size from the collar stricture to the mid-thorax constriction; on the lower thorax, the pores are large, rounded and somewhat aligned longitudinally.

Dimensions. Based on five specimens. Length of apical horn: 62$69 \mu \mathrm{m}(67 \mu \mathrm{m})$; of cephalis: $41-53 \mu \mathrm{m}(46 \mu \mathrm{m})$; of thorax: 102$153 \mu \mathrm{m}(110 \mu \mathrm{m})$; width of upper thorax: 102-127 $\mu \mathrm{m}(109 \mu \mathrm{m})$.

Occurrence. Sporadic from the C. antiqua through the E. punctatum Zone (Early to Middle Miocene); rare from the C. humerus to the C. spongothorax Zone (Middle to Late Miocene).

Remarks. Gondwanaria clarae differs from $G$. cylindrica Funakawa, 2000 in the shape of the cephalis (ellipsoidal in G. clarae and hemispherical in G. cylindrica) and the presence in G. clarae of both a clear, strong collar stricture and a constriction of the thorax below the wings. It differs from $G$. nigriniae Petrushevskaya in Petrushevskaya \& Kozlova, 1979 in having three long, subhorizontal, tribladed wings and in the lower part of the thorax being approximately the same width as the upper part. It differs from the specimens illustrated in Caulet (1991, pl. 2, fig. 11) as Pteropilium contiguum (Ehrenberg) and in Petrushevskaya \& Kozlova (1972, pl. 29, figs 8-10) as Pteropilium? sp. aff. Pterocanium contiguum (Ehrenberg) group in the absence of longitudinal alignment of the thoracic pores (which are also larger in G. clarae) and the postcephalic part of the shell being, in Caulet's specimen, seemingly separated into a thorax and an abdomen by a lumbar septum, whereas in $G$. clarae there is no separation between the upper and the lower thorax. It also differs from Stichopilium campanulatum Haeckel, 
1887 for the same reasons as from the latter, in the wings being longer and tribladed and in the cephalis being longer. The specimen illustrated as S. campanulatum in Nishimura \& Yamauchi (1984, pl. 35, fig. 7) also seems to have a somewhat pyramidal thorax whereas G.clarae has a campanulate upper thorax.

Genus Stichophormis Haeckel, 1881

Type species. Stichophormis cornutella Haeckel, 1887

Stichophormis? cheni $\mathrm{n}$. sp.

(Pl. 4, figs 2A-4)

1975 ?Lithostrobus(?) clava (Ehrenberg); Petrushevskaya: 14, figs 1-2 (non Lithocampe clava Ehrenberg, 1874 in Ogane et al., 2009, pl. 22, fig. 2a-c).

1975 Stichophormis sp. Chen: 462-463, pl. 13, fig. 8.

1990 Stichophormis sp. Chen; Abelmann: 698, pl. 8, fig. 9.

1992 Cyrtolagena aglaogena (Takahashi) (sic); Wang \& Yang: pl. 2, fig. 11 (non Cyrtopera aglaolampa Takahashi, 1991, p. 119, pl. 40, fig. 7).

1999a Cyrtolagena cf. aglaolampa (Takahashi); O’Connor: 500, pl. 4, figs L-M (not N).

Derivation of name. After Pei-Hsin Chen who first described this species.

Diagnosis. Numerous segments; thick wall; last segment tapering to a mouth; no apical horn.

Holotype. Plate 4, figs 2A-B; sample 119-744A-8H-1 60/62 cm (Early/Middle Miocene); ECO-027.

Material. 23 specimens were observed from ODP Sites 744, 748 and 751 .

Description. Spindle-shaped shell consisting of usually 11 thickwalled segments $(10-12)$. Up to the nine first segments, the shell is conical and the segments barrel-shaped. The two last segments are inverted truncate-conical. The change in contour occurs either on the lower part of the ninth segment or on the upper part of the tenth.

The hyaline cephalis consists of two parts: an upper part which is spherical and a cylindrical lower part. The two parts are separated by a constriction (see Pl. 4, fig. 2B). None of the internal spines was observed in our material. The upper part of the cephalis is rough and poreless while the lower part bears a few randomly distributed, small pores.

Pores on the following segments are relatively small, rounded and aligned transversally. The second through the eighth segments are approximately equal in length and have three to five rows of pores. The ninth and the tenth segments are usually longer and, therefore, have more pore rows. The last segment has somewhat larger pores that are loosely aligned transversally too. This segment ends in a distal opening or mouth with a poreless rim that may have some small poreless teeth.

Most specimens have three wings that are flat and end with a conical spine. Large rounded pores can sometimes be observed on the panel that connects the wings with the main body. They arise from the third or fourth segment.
Dimensions. Based on four specimens. Length: 304-326 $\mu \mathrm{m}$ (314 $\mu \mathrm{m})$; width: 119-145 $\mu \mathrm{m}(132 \mu \mathrm{m})$.

Occurrence. Very rare from the $C$. golli regipileus to the lower A. golownini Zone (Early to Middle Miocene).

Remarks. Stichophormis? cheni differs from Cyrtolagena laguncula Haeckel, 1887 in having a thick wall, in ending on a differentiated mouth and in the shape of the cephalis; and from Cyrtopera aglaolampa Takahashi, 1991 in the last segment, in the latter, being globular and accounting for more than a third of the total height, and in the absence of an apical horn. The cephalis of $S$.? cheni seems rather similar to that of the Cretaceous Amphipyndax but, since the internal spines were not actually seen on any of the specimens, the two cannot be compared efficiently. The lack of apical horn or any discernable apical spine makes the affinity with S. cornutella and, therefore, the generic assignment to Stichophormis doubtful. Petrushevskaya's tentative assignment of her form to L. clava Ehrenberg, 1874 is clearly incorrect, as the newly figured type-series material in Ogane et al. (2009) shows. L. clava has much longer segments, fewer in number, lacks wings and is more similar to the modern concept of Stichocorys. We are not sure if Petrushevskaya's specimens are conspecific with ours, as the photographs are of poor quality. The number of segments and development of external wings, however, appear to differ from our material. Petrushevskaya's material is of Paleocene age. Family Plagiacanthidae Hertwig, 1879, emend.
Petrushevskaya, 1971

Genus Antarctissa Petrushevskaya, 1967

Type species. Lithobotrys denticulata Ehrenberg, 1844b

Antarctissa ballista n. sp.

(P1. 6, figs 4A-6B; Fig. 4)

2001 Antarctissa 'bullet' Lazarus: 21, pl. P1, figs 5-8.

Derivation of name. ballista is Latin for projectile.

Diagnosis. Cephalis and thorax undifferentiated; internal ring with six lateral beams; robust spine A free in the cephalis.

Holotype. Plate 6, fig. 6A-B; sample 120-751A-6H-1 98/102 cm (Late Miocene); ECO-041.

Material. 236 specimens were observed from ODP Sites 746, 747 and 751 .

Description. Two-segmented shell with a cephalis and a thorax that are not distinguishable externally by any constriction, furrow or shoulder. The thorax is short and closed in most specimens. The cephalis apex is slightly rounded (just a little less squared than the thorax termination).

Spine A is robust (as are the other spines) and free in the cephalic cavity; it reaches the wall approximately at mid-width (slightly closer to the dorsal side than to the opposite side) and thus creates a furrow, in most specimens, that can make the cephalis look bilobate. The axobate is just below spine $\mathrm{A}$ and is almost long enough to reach 


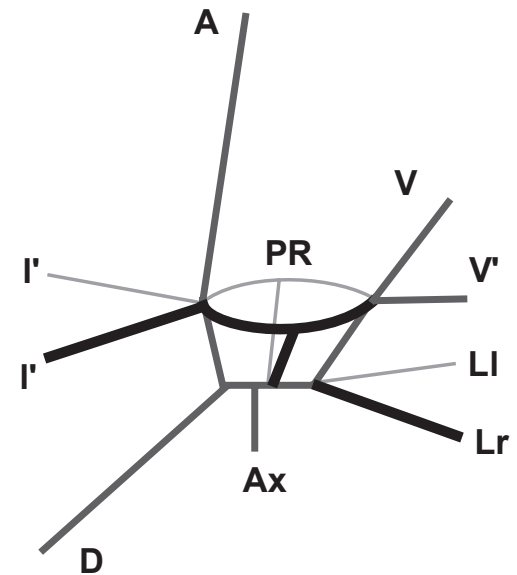

Fig. 4. Schematic illustration of Antarctissa ballista n. sp. inner structure. Terminology after Sugiyama, 1993. PR, proximal ring; V', secondary vertical spine.

termination of the thorax. Spine D is directed downward - very similar to that of A. denticulata and A. cylindrica Petrushevskaya, 1975 - and reaches the wall near the thorax closure. Specimens seen from below or above (see Pl. 6, fig. 4A) show the presence of an internal ring, similar to that of Helotholus vema Hays, 1965. The ring structure is supported by six beams: five horizontal or subhorizontal (Ll, Lr, V' and two l' according to Sugiyama's (1993) terminology, see Fig. 4), plus the downward-directed D spine. This structure is almost at the equator of the shell; the cephalic chamber and the thorax are thus of almost the same length as well as the same width.

The wall is rough, crested and bears only a few pores, unequal in size and arranged randomly. No other ornamentation (such as horns) has been seen on any specimens.

Dimensions. Based on six specimens. Length: $66-83 \mu \mathrm{m}(74 \mu \mathrm{m})$; width: $58-70 \mu \mathrm{m}(66 \mu \mathrm{m})$; length of cephalis: $36-44 \mu \mathrm{m}(40 \mu \mathrm{m})$.

Occurrence. Rare from the C. spongothorax to the Upsilon Zone (Middle Miocene to Early Pliocene), common in the A. australis and S. vesuvius Zone (Late Miocene).

Remarks. Antarctissa ballista differs from all other members of the genus Antarctissa mostly in its median, free, robust spine A. Its overall shape is rather similar to that of Botryopera pseudoantarctissa Petrushevskaya in Petrushevskaya \& Kozlova (1979) and A. whitei Bjørklund, 1976a, yet the length and width ratio of the two segments, the closed thorax and the lack of any external spine or spongy meshwork make it unique.

Genus Botryopera Haeckel, 1887

Type species. Botryopera cyrtoloba Haeckel, 1887

Botryopera? gibbera $\mathrm{n}$. sp. (P1. 7, figs 3A-6B)

Derivation of name. gibbera is Latin for hunchback.

Diagnosis. Characterized by a large hump between spine A and spine D.
Holotype. Plate 7, figs 3A-B; sample 120-751A-10H-4 98/102 cm (Middle Miocene); ECO-039.

Material. 160 specimens were observed from ODP Sites 744, 747, 748 and 751.

Description. Two-segmented shell with a thorax slightly longer ( $c$. 1.2 times) than the cephalis which is separated into two chambers: an antecephalic 'hump' between spines A and D and a eucephalic chamber between spines A and V. Externally, the two chambers are separated by a furrow along AL while the eucephalic chamber wall and the thoracic wall are separated by a furrow along VL. Spines $\mathrm{A}$ and $\mathrm{V}$ both continue outside as small triangular horns. The wall of both cephalic chambers also bears numerous thorns. The antecephalic chamber is variable in size: it can be only a quarter of the volume of the eucephalic chamber (see Pl. 7, figs 4A-B and $6 \mathrm{~A}-\mathrm{B}$ ) as well as up to three-quarters (see Pl. 7, figs $3 \mathrm{~A}-\mathrm{B}$ ).

The thorax is short and somewhat barrel-shaped. Its termination is ragged; it bears no specific ornamentation nor does it flare. Pores on both segments are circular to elliptical and irregular both in size and in disposition.

Dimensions. Based on six specimens. Length: 69-86 $\mu \mathrm{m}$ (78 $\mu \mathrm{m})$; width at collar: 43-56 $\mu \mathrm{m}$ (49) $\mu \mathrm{m}$; length of eucephalic chamber: $33-47 \mu \mathrm{m}(41 \mu \mathrm{m})$; width of antecephalic chamber: 17$29 \mu \mathrm{m}(22 \mu \mathrm{m})$.

Occurrence. Very rare from the A. golownini to the S. vesuvius Zone (Middle to Late Miocene).

Remarks. Botryopera? gibbera differs from other small Lophophaenids in its fairly large antecephalic chamber. Because of this peculiar character, the assignment to genus Botryopera remains uncertain.

\section{Genus Ceratocyrtis Bütschli, 1882}

Type species. Cornutella cuccularis Ehrenberg, 1874

Ceratocyrtis dolvenae n. sp.

(P1. 5, figs 2A-B, 5A-6B)

Derivation of name. After Jane K. Dolven for her support of radiolarian research via radiolaria.org.

Diagnosis. Large, more or less aligned, quadrangular, thoracic pores; cephalis and thorax indistinguishable externally; spines L1, $\mathrm{Lr}$ and D extend laterally at cephalic suture.

Holotype. Plate 5, figs 5A-B; sample 120-748B-6H-3 45/47 cm (Early Miocene); ECO-048, circle 2.

Material. 33 specimens were observed from ODP Sites 690, 744, 747,748 and 751 .

Description. Two-segmented, conical shell with a cephalis and a thorax that are not separated externally by any furrow, constriction, shoulder or even change in contour. The cephalis is considerably smaller than the thorax. The angle formed by the shell is obtuse. 
The cephalis is dome-shaped. Spines V, Ll, Lr, A and D are usually all protruding outside as thin, conical spines. Spines Ll, Lr and $\mathrm{D}$ are roughly in the same plane as the median bar ( $\mathrm{Pl}$. 5, fig. 2B), whereas spine A is orthogonal to it. The axobate is also present as relatively short, simple, downward-orientated, cylindrical spines approximately at the junction between Ll, Lr, V and the median bar.

The cephalic wall is thorny and bears small, circular to subelliptical, irregularly distributed pores. Pores on the thoracic wall are rectangular with rounded angles, becoming larger and aligned along thin longitudinal bars as they are further from the cephalis.

Dimensions. Based on four specimens. Diameter of cephalic pores: $2-15 \mu \mathrm{m}(7 \mu \mathrm{m})$; of thoracic pores: $18-47 \mu \mathrm{m}(28 \mu \mathrm{m})$.

Occurrence. Sporadic from the $C$. golli regipileus to the lower Upsilon Zone (Early Miocene to Early Pliocene).

Remarks. Ceratocyrtis dolvenae differs from C. galeus (Cleve) 1899 in the pattern, the size and the shape of its thoracic pores. It also differs from C. morawanensis Funakawa, 1995 in the latter having a cephalis distinct from the thorax by a collar stricture, and having a tribladed apical horn. It finally differs from other known members of Ceratocyrtis in having prominent lateral spines extending from the cephalic suture.

Genus Lithomelissa Ehrenberg, 1847 sensu Petrushevskaya, 1971

Type species. Lithomelissa microptera Ehrenberg, 1854

Lithomelissa vespa $\mathrm{n}$. sp. (P1. 7, figs 7A-B, 9A-B and 10)

Derivation of name. vespa is Latin for wasp.

Diagnosis. One long, slender apical horn; three short wings; two (three?) short, thin, subapical horns; cephalis and thorax undifferentiated.

Holotype. Plate 7, figs 7A-B; sample 119-744A-4H-2 59/61 cm (Late Miocene); ECO-037, circle 2.

Material. 56 specimens were observed on Sites 744 and 751.

Description. Two-segmented shell with a cephalis and a thorax that are not distinguishable externally by any constriction, furrow or shoulder. The cephalis is longer than the thorax.

Spine A is free in the cephalic cavity and protrudes as a long (1.5 times to twice as long as the shell itself), slender, cylindrical horn. Spines D, Ll and Lr protrude as short, triangular (with a thick base) wings from the thoracic wall, slightly lower than the level of the median bar. The axobate is short. Spine V joins the cephalic wall subhorizontally and does not seem to extend outside the wall. Two (three?) short, thin, conical, upward-directed spines appear to extend subapically from apophyses branching from spine A: apophyses $a$, according to Petrushevskaya's (1971) terminology.

Some specimens have a thick, crested wall (see Pl. 7, figs $7 \mathrm{~A}-\mathrm{B}$ and $9 \mathrm{~A}-\mathrm{B}$ ), but commonly the wall is thin and smooth (see P1. 7, fig. 10). Specimens with a thick wall have their thorax closed by a sieve plate. In both cases, pores on thorax are somewhat bigger than the cephalic ones; but, on both segments, they are randomly distributed, uneven in size and subelliptical.

Dimensions. Based on four specimens. Length (without apical horn): $54-70 \mu \mathrm{m}(61 \mu \mathrm{m})$; of cephalis: $30-35 \mu \mathrm{m}(34 \mu \mathrm{m})$; of apical horn: 71-110 $\mu \mathrm{m}(97 \mu \mathrm{m})$; width: 46-58 $\mu \mathrm{m}(53 \mu \mathrm{m})$.

Occurrence. L. vespa is sporadic in the A. golownini and the lower C. spongothorax Zone (Middle Miocene); rare in the middle and upper $C$. spongothorax and in the A. australis Zone (Late Miocene).

Remarks. Lithomelissa vespa differs from most Lophophaenidae in its horn combination: $\mathrm{A}, \mathrm{D}, \mathrm{Ll}, \mathrm{Lr}$ and two more branching from spine A. This combination, however, is shared by L. tricornis Chen, 1975. L. vespa differs from the latter in its unusually long apical horn, in its cephalis/thorax ratio and in the overall shape of the shell. Furthermore, the horns of L. tricornis are all of rather similar size and shape, whereas each set of horns in $L$. vespa is different from one another.

Genus Lophophaena Ehrenberg, 1847 sensu Petrushevskaya, 1971

Type species. Lophophaena galeaorci Ehrenberg, 1854

Lophophaena? leberu n. sp.

(P1. 5, figs 9A-11B)

Derivation of name. After the mythical creature Leberou, whose name derives from the Occitan lèbre (hare).

Diagnosis. Long apical horn; long secondary horn halfway between spines $\mathrm{A}$ and $\mathrm{V}$; no feet; no ribs.

Holotype. Plate 5, figs 9A-B; sample 120-748B-7H-2 45/47 cm (Early Miocene); ECO-030.

Material. 25 specimens were observed from ODP Sites 747, 748 and 751 .

Description. Two-segmented shell with a long, truncated-conical thorax, approximately twice as long as the ellipsoidal cephalis. The shell tilts on the ventral side. The cephalis and the thorax are separated by a shoulder along AL and a furrow following VL.

Spine A is fused to the cephalic wall and protrudes outside the wall apically as a robust, blade-shaped horn (c. 1-1.5 times the height of the cephalis). Spine $\mathrm{V}$ protrudes at the junction of the cephalis and the thorax as a short triangular horn. Spines D, L1 and Lr join the thoracic wall and, sometimes, spine D extends outside as a very short wing. There is a change in contour of the thorax where those spines join the wall (concave for spine D, convex for spines $\mathrm{Ll}$ and $\mathrm{Lr}$ ). The cephalis bears an additional horn halfway between the apical and the ventral horn: it is rather similar in shape to the apical horn but smaller; it does not seem to be linked to any internal spine. Some rare specimens also bear numerous small additional horns scattered on the cephalis (see Pl. 5, figs 11A-B).

The thoracic wall is smooth, with numerous small pores, more or less arranged in a hexagonal pattern, but somewhat irregular in size. The cephalic wall is similar to the thoracic wall, yet some specimens have a crested cephalis. Thorax termination is ragged. 
Dimensions. Based on five specimens. Length (without horns): 102-132 $\mu \mathrm{m}(119 \mu \mathrm{m})$; of cephalis: $37-45 \mu \mathrm{m}(41 \mu \mathrm{m})$; of apical horn: $30-54 \mu \mathrm{m}(42 \mu \mathrm{m})$; of additional horn: $25-30 \mu \mathrm{m}(28 \mu \mathrm{m})$.

Occurrence. Rare from the $C$. antiqua Zone to the E. punctatum Zone (Early Miocene); sporadic from the E. punctatum to the A. australis Zone (Middle to Late Miocene).

Remarks. Lophophaena? leberu differs from other Lophophaenidae and, in particular, from the otherwise similar L. thaumasia Caulet, 1991, in its long, robust, additional horn.

Genus Syscioscenium Sugiyama, 1992

Type species. Syscioscenium velamen Sugiyama, 1992

Syscioscenium? wabisabi n. sp. (P1. 6, figs 1A-3B)

Derivation of name. After the Japanese aesthetic concept wabisabi: the beauty that is imperfect, impermanent and incomplete.

Diagnosis. Numerous thorns branching together distally; bilobed cephalis.

Holotype. Plate 6, figs 1A-B; sample 120-751A-7H-4 98/102 cm (Late Miocene); ECO-042.

Material. 298 specimens were observed from ODP Sites 744, 746, 747, 748 and 751 .

Description. Two-segmented shell with a short (up to $c$. 1.2 times the length of the cephalis) flaring thorax and a cephalis with an approximately median indentation where spine A joins the wall.

Spine A is free in the cephalis and continues outside as a small, tribladed - at least at the base - apical horn. Spines D, Ll and Lr extend approximately horizontally and sometimes continue outside as slender downward-directed horns. The median bar bears a very small axobate (most often just an indentation, see Pl. 6, fig. 3B). Spine V is present and is almost horizontal too; it sometimes protrudes outside the wall as a very short, upward-directed tribladed horn. All the internal spines are rather thick. Collar stricture is marked by a small constriction externally.

The cephalic wall is thick, it can be smooth or rough depending on the specimen, and is almost poreless: some specimens have a few small, rounded pores. The thoracic wall is smooth and bears some larger, circular to elliptical pores of variable size and uneven distribution. The thorax ends with upward-directed small thorns. Both the cephalis and the thorax bear a fairly large amount of slender thorns (that can be as long as the apical horn). Those thorns branch distally to form ultimately on some specimens a secondary 3D meshwork made of thin anastomosed bars.

Dimensions. Based on eight specimens. Length: $62-78 \mu \mathrm{m}(70$ $\mu \mathrm{m})$; of cephalis: $26-34 \mu \mathrm{m}(31 \mu \mathrm{m})$; of projections: $16-37 \mu \mathrm{m}$ $(24 \mu \mathrm{m})$; collar width: $42-53 \mu \mathrm{m}(47 \mu \mathrm{m})$.

Occurrence. Rare from the $C$. humerus to the A. challengerae Zone (Middle to Late Miocene).
Remarks. Syscioscenium? wabisabi differs from $S$. velamen in the thorns branching to form a secondary meshwork and in having a spine V. The sethophormid structure described by Sugiyama (1992) on S. velamen was not observed here. The assignment to the genus Syscioscenium is, therefore, questionable.

Genus Trisulcus Popofsky, 1913

Type species. Trisulcus triacanthus Popofsky, 1913

Trisulcus pinguiculus $\mathrm{n}$. sp.

(P1. 7, figs 8A-B, 11A-12B)

Derivation of name. pinguiculus is Latin for chubby.

Diagnosis. Three large thoracic lobes; small cephalis with a short apical horn; thorax with large pores.

Material. 107 specimens were observed from ODP Sites 744, 748 and 751 .

Holotype. Plate 7, figs 8A-B (specimen on the right); sample 120748B-8H-6 45/47 cm (Late Oligocene/Early Miocene); ECO-036.

Description. Two-segmented shell with a trilobate thorax, $c$. three times wider than the cephalic chamber. The lobes are separated by short, rather shallow furrows formed by the junction of spines $\mathrm{D}, \mathrm{Ll}$ and $\mathrm{Lr}$ with the thoracic wall. Those spines protrude outside the wall as really small, slender spines on most specimens. Thorax termination is ragged and of nearly the same width as its upper part. In some specimens, the dorsal side of the upper thorax (i.e. the two lobes separated by the dorsal furrow) is slightly bigger than the lateral one.

The cephalic chamber is approximately hemispherical; spine A is fused to the wall and protrudes outside subapically as a very short three-bladed horn. There is a furrow between the cephalis and the thorax, where spine $\mathrm{V}$ joins the wall. None of the specimens bears a ventral horn, but some rare specimens (see Pl. 7, figs $12 \mathrm{~A}-\mathrm{B}$ ) bear some short (nearly equal to the apical horn in length and width), additional horns at the apex and on the thoracic lobes. The axobate has never been observed.

The cephalic pores are small and roundish, but somewhat larger and downwardly elongated near the furrow between the cephalis and the thorax. The thoracic pores are larger yet unequal in size, elliptical and randomly distributed. Pores on the lower part of the thorax are larger than the ones on the upper part. The cephalic wall is rougher than the thoracic wall (some specimens have a slightly crested cephalic wall).

Dimensions. Based on seven specimens. Width of cephalis: $32-$ $40 \mu \mathrm{m}(36 \mu \mathrm{m})$; of thorax at shoulders: 66-94 $\mu \mathrm{m}(82 \mu \mathrm{m})$; total length (without apical horn): 72-112 $\mu \mathrm{m}(89 \mu \mathrm{m})$.

Occurrence. T. pinguiculus is common in samples from the $S$. radiosa to the C. golli regipileus Zone (Early Miocene) and rare from the E. punctatum to the A. golownini Zone (Early to Middle Miocene).

Remarks. Trisulcus pinguiculus differs from T. triacanthus in having a rougher surface, larger pores and smaller apophyses. The thorax in T. pinguiculus is shorter and does not taper downward. 
The furrows between the thoracic lobes are deeper than in T. triacanthus. It also differs from other small dicyrtids, such as species of the genera Antarctissa, Botryopera or Lithomelissa, in that the cephalis is partially sunken into the thorax cavity, in the cephalis/ thorax width ratio and in the three distinctive shoulders present in the genus Trisulcus.

Family Trissocyclidae Haeckel, 1881, emend. Goll, 1968 Genus Dendrospyris Haeckel, 1881, emend. Goll, 1968

Type species. Ceratospyris stylophora Ehrenberg, 1874

Dendrospyris? jobstae n. sp.

(Pl. 4, figs 7, 8A-B, 11A-12B)

Derivation of name. After Anne Jobst, for her long effort in curating and databasing the Ehrenberg Collection.

Diagnosis. Characterized by its large pores, its relatively thin bars and its longitudinally elongated shell.

Holotype. Plate 4, fig. 7; sample 119-745B-14H-6 53/55 cm (Late Pliocene); ECO-035.

Material. 73 specimens were observed from ODP Sites 745, 747 and 751 .

Description. The latticed shell is made of few large, circular to subelliptical pores that are loosely arranged according to a hexagonal pattern and are separated by relatively thin, crested bars. Some smaller pores are sometimes intercalated between the larger ones, and the pores at the apex are also usually smaller. The latticed shell continues below the basal ring as a cylindrical thorax. Some specimens show a slight constriction at the basal and the sagittal ring. The latticed shell is linked to the D-shaped sagittal ring by $8($ ?) pairs of bars and, on front view, by the frontal bar. The two sagittal-lattice pores just above this frontal bar are generally larger than the others (see Pl. 4, figs 8A, 11A and 12B).

The shell outline is somewhat narrow (laterally) but elongated (longitudinally).

Dimensions. Based on six specimens. Length of sagittal ring: 79$90 \mu \mathrm{m}(85 \mu \mathrm{m})$; width of basal ring: 76-99 $\mu \mathrm{m}(88 \mu \mathrm{m})$; maximum width of cephalic lobes: $82-109 \mu \mathrm{m}(98 \mu \mathrm{m})$.

Occurrence. Rare to common from the Tau to the lower Upsilon Zone (Early Pliocene).

Remarks. Dendrospyris? jobstae differs from D. stabilis Goll, 1968 and D. haysi Chen, 1975 in its outline being narrower but longer, in its sagittal and basal constriction being slighter (and even absent in some most specimens) and in its pores being larger with smaller crested bars.

\section{CONCLUSIONS}

With the exception of a few highly sporadic taxa (Ceratocyrtis dolvenae, Actinomma nigriniae, Carposphaera? annikae and Spirocyrtis? hollisi), the species described in this paper were all, even for the rarest one, present relatively continuously in the studied sections: it is likely that they will be of stratigraphical or palaeoenvironmental interest in the future. Early and Late Miocene radiolarian zonations are particularly poor in marker species in the Southern Ocean (Lazarus, 1992), therefore fairly common species such as Cystophormis gargantua, Orodapis hericina or Trisulcus pinguiculus (for the Early Miocene) and short-ranging taxa such as Acrosphaera cuniculiauris, Antarctissa ballista, Dendrospyris? jobstae, Botryopera gibbera, Lithomelissa vespa, Siphostichartus jahnae or Amphimelissa? hibernifortuna (for the Late Miocene) might prove useful to increase the biostratigraphical resolution of this region. Trisulcus pinguiculus, Cystophormis gargantua, Orodapis hericina, O.? ferrealuma and Antarctissa ballista are quantitatively important components of these faunas as well: $T$. pinguiculus in particular peaks at $c .15 \%$ near the Oligocene/Miocene boundary and should be included in future palaeoecological studies. Furthermore, such species as Amphimelissa? hibernifortuna and Syscioscenium? wabisabi exhibit unique morphological features that may shed a new light on nassellarian recent evolution. Similarly, Antarctissa ballista, with its proximal ring, provides more information to help untangle the intricate taxonomy of the Antarctissids and the species close to Helotholus vema (Kellogg, 1975; Petrushevskaya, 1986; Lazarus, 1990; Sugiyama, 1993).

\section{ACKNOWLEDGEMENTS}

The authors would like to thank Annika Sanfilippo, Kjell R. Bjørklund and John Gregory for their helpful comments, IODP for providing the samples and the DFG (German Science Foundation) for supporting the project.

\section{Manuscript received 12 February 2010 \\ Manuscript accepted 11 May 2011 \\ Scientific editing by F. John Gregory}

\section{REFERENCES}

Abelmann, A. 1990. Oligocene to middle Miocene radiolarian stratigraphy of southern high latitudes from Leg 113, Sites 689-690, Maud Rise. In: Barker, P.F., Kennett, J.P. et al. (Eds), Proceedings of the Ocean Drilling Program, Scientific Results, College Station, TX (Ocean Drilling Program), 113: 675-708.

Abelmann, A. 1992a. Radiolarian taxa from Southern Ocean sediment traps (Atlantic sector). Polar Biology, 12: 373-385.

Abelmann, A. 1992b. Early to middle Miocene radiolarian stratigraphy of the Kerguelen Plateau, leg 120. In: Wise, S.W. Jr. et al. (Eds), Proceedings of the Ocean Drilling Program, Scientific Results, College Station, TX (Ocean Drilling Program), 120: 757-783.

Abramoff, M.D., Magelhaes, P.J. \& Ram, S.J. 2004. Image processing with ImageJ. Biophotonics International, 11(7): 36-42.

Bailey, J.W. 1856. Notice of microscopic forms found in the soundings of the Sea of Kamtschatka. American Journal of Science and Arts, 2nd Series, 22: 1-6.

Barron, J.A., Baldauf, J.G., Barrera, E. et al. 1991. Biochronologic and Magnetochronologic synthesis of leg 119 sediments from the Kerguelen Plateau and Prydz Bay, Antarctica. In: Barron, J. \& Larsen, B. (Eds), Proceedings of the Ocean Drilling Program, Scientific Results, College Station, TX (Ocean Drilling Program), 119: 813-847.

Bjørklund, K.R. 1976a. Radiolaria from the Norwegian Sea, Leg 38 of the Deep Sea Drilling Project. In: Talwani, M., Udintsev, G. et al. (Eds), Initial Reports of the Deep Sea Drilling Project, Washington (US Govt Printing Office), 38: 1101-1168.

Bjørklund, K.R. 1976b. Actinomma haysi, n. sp., its Holocene distribution and size variation in Atlantic Ocean sediments. Micropaleontology, 23(1): 114-126 
Boltovskoy, D. 1998. Classification and Distribution of South Atlantic recent Polycystine Radiolaria. Palaeontologica Electronica, 1(2): http:// palaeo-electronica.org/1998_2/boltovskoy/issue2.htm

Bütschli, O. 1882. Beiträge zur Kenntnis der Radiolarienskelette, insbesondere der Cyrtida. Zeitschrift für wissenschaftliche Zoologie, 36: 485-540.

Campbell, A.S. \& Clark, B.L. 1944. Miocene Radiolarian faunas from Southern California. Geological Society of America, Special Papers, 51: $1-76$.

Caulet, J.P. 1986. Radiolarians from the Southwest Pacific. In: Kennett, J.P., von der Borch, C.C. et al. (Eds), Initial Reports of the Deep Sea Drilling Project, Washington (US Govt Printing Office), 90: 835-861.

Caulet, J.P. 1991. Radiolarians from the Kerguelen Plateau, ODP Leg 119. In: Barron, J. \& Larsen, B. (Eds), Proceedings of the Ocean Drilling Program, Scientific Results, College Station, TX (Ocean Drilling Program), 119: 513-546.

Cavalier-Smith, T. 2002. The phagotrophic origin of eukaryotes and phylogenetic classification of Protozoa. International Journal of Systematic and Evolutionary Microbiology, 52: 297-354.

Chen, P.H. 1975. Antarctic Radiolaria. In: Hayes, D.E., Frakes, L.A. et al. (Eds), Initial Reports of the Deep Sea Drilling Project, Washington (US Govt Printing Office), 28: 437-513.

Cleve, P.T. 1899. Plankton collected by the Swedish Expedition to Spitzbergen in 1898. Kongliga Svenska Vetenskaps-Akademiens Handlingar, 32: 25-51.

De Wever, P., Sanfilippo, A., Riedel, W.R. \& Gruber, B. 1979. Triassic radiolarians from Greece, Sicily and Turkey. Micropaleontology, 25(1): 75-110.

Dumitrica, P. 1991. Middle Triassic Tripedurnulidae, n. fam. (Radiolaria) from the eastern Carpathians (Romania) and Vicentinian Alps (Italy). Revue de Micropaléontologie, 34(4): 261-278.

Ehrenberg, C.G. 1838. Über die Bildung der Kreidefelsen und des Kreidemergels durch unsichtbare Organismen. Königlichen Preußischen Akademie der Wissenschaften zu Berlin, Abhandlungen, Jahre 1838: 59-147.

Ehrenberg, C.G. 1844a. Über 2 neue Lager von Gebirgsmassen aus Infusioren als Meeres-Absatz in Nord-Amerika und eine Vergleichung derselben mit den organischen Kreide-Gebirgen in Europa und Afrika. Monatsberichte der Königlich Preußischen Akademie der Wissenschaften zu Berlin, Jahre 1844: 57-97.

Ehrenberg, C.G. 1844b. Einige vorlaufige Resultate seiner Untersuchungen der ihm von der Sudpolreise des Captain Ross, so wie von den Herren Schayerund Darwin zugekommenen Materialien über das Verhalten des kleinsten Lebens in den Oceanen und den grossten Bisher zuganglichen Tiefen des Weltmeeres. Königlichen Preußischen Akademie der Wissenschaften zu Berlin, Bericht, Jahre 1844: 182-207.

Ehrenberg, C.G. 1847. Über die mikroskopischen kieselschaligen Polycystinen als mächtige Gebirgsmasse von Barbados und über das Verhältniss deraus mehr als 300 neuen Arten bestehenden ganz eigenthümlichen Formengruppe jener Felsmasse zu den jetzt lebenden Thieren und zur Kreidebildung. Königlichen Preußischen Akademie der Wissenschaften zu Berlin, Bericht, Jahre 1847: 40-60.

Ehrenberg, C.G. 1854. Die systematische Charakteristik der neuen Mikroskopischen Organismen des Tiefen Atlantischen Oceans. Königlichen Preußischen Akademie der Wissenschaften zu Berlin, Bericht, Jahre 1854: 236-250.

Ehrenberg, C.G. 1872. Mikrogeologische Studien über das kleinste Leben der Meeres-Tiefgründe aller Zonen und dessen geologischen Einfluss. Monatsberichte der Königlich Preußischen Akademie der Wissenschaften zu Berlin: 265-322.

Ehrenberg, C.G. 1874. Grössere Felsproben des Polycystinen-mergels von Barbados mit weiteren Erläuterungen. Monatsberichte der Königlich Preußischen Akademie der Wissenschaften zu Berlin, Jahre 1873: 213-263. Ehrenberg, C.G. 1876. Fortsetzung der mikrogeologischen Studien als Gesammt übersicht der mikroskopischen Paläontologie gleichartig analysirter Gebirgsarten der Erde, mit specieller Rücksicht auf den Polycystinen-mergel Von Barbados. Königlichen Preußischen Akademie der Wissenschaften zu Berlin, Abhandlungen, Jahre 1875: 1-225.
Foreman, H.P. 1973. Radiolaria of Leg 10 with systematics and ranges for the families Amphipyndacidae, Artostrobiidae, and Theoperidae. In: Worzel, J.L., Bryant, W. et al. (Eds), Initial Reports of the Deep Sea Drilling Project, Washington (US Govt Printing Office), 10: 407-474.

Friend, J.K. \& Riedel, W.R. 1967. Cenozoic orosphaerid radiolarians from tropical Pacific sediments. Micropaleontology, 13(2): 217-232.

Funakawa, S. 1995. Lophophaeninae (Radiolaria) from the upper Oligocene to lower Miocene and intrageneric variation in their internal skeletal structures. Journal of Geosciences, Osaka City University, 38: $13-59$.

Funakawa, S. 2000. Internal skeletal structures of the Cenozoic genera Gondwanaria, Lipmanella and Lithomelissa (Plagiacanthidae, Nassellaria) and their taxonomy. Micropaleontology, 46(2): 97-121.

Gersonde, R., Abelmann, A., Burckle, L.H. et al. 1990. Biostratigraphic synthesis of Neogene siliceous microfossils from the Antarctic Ocean, ODP Leg 113 (Weddell Sea). In: Barker, P.F., Kennett, J.P. et al. (Eds), Proceedings of the Ocean Drilling Program, Scientific Results, College Station, TX (Ocean Drilling Program), 113: 915-936.

Goll, R.M. 1968. Classification and phylogeny of Cenozoic Trissocyclidae (Radiolaria) in the Pacific and Caribbean Basins, Part I. Journal of Paleontology, 42(6): 1409-1432.

Goll, R.M. 1980. Pliocene-Pleistocene radiolarians from the East Pacific Rise and the Galapagos spreading, Deep Sea Drilling Project Leg 54. In: Rosendahl, B.R., Hekinian, R. et al. (Eds), Initial Reports of the Deep Sea Drilling Project, Washington (US Govt Printing Office), 54: 425-453.

Haeckel, E. 1860. Über neue, lebende Radiolarien des Mittelmeeres und die dazu gehörigen Abbildungen. Monatsberichte der Königlich Preußischen Akademie der Wissenschaften zu Berlin, Jahre 1860: 794-817.

Haeckel, E. 1862. Die Radiolarien (Rhizopoda Radiaria). Reimer, Berlin, 572pp.

Haeckel, E. 1881. Entwurf eines Radiolarien-systems auf grund von studien der Challenger-Radiolarien. Jenaische Zeitschrift für Naturwissenschaft, 15: 418-472.

Haeckel, E. 1887. Report on the Radiolaria collected By H.M.S. Challenger during the years 1873-1876. Report on the Scientific Results of the voyage of H.M.S. Challenger during the years 1873-1876, Zoology, 18.

Harwood, D.M., Lazarus, D.B., Abelmann, A. et al. 1992. Neogene integrated magnetobiostratigraphy of the central Kerguelen Plateau, leg 120. In: Wise, S.W. Jr. et al. (Eds), Proceedings of the Ocean Drilling Program, Scientific Results, College Station, TX (Ocean Drilling Program), 120: 1031-1052.

Hays, J.D. 1965. Radiolaria and late Tertiary and Quaternary history of Antarctic seas. In: Llano, G.A. (Ed.), Biology of the Antarctic Seas 2, Antarctic Research Serie, 5: 125-184.

Hertwig, R. 1879. Der organismus der Radiolarien. G. Fischer, Jena, 149pp. Hollis, C.J. 2002. Biostratigraphy and paleoceanographic significance of Paleocene radiolarians from offshore Eastern New Zealand. Marine Micropaleontology, 46: 265-316.

Jörgensen, E. 1905. The Protist plankton and the diatoms in bottom samples. VII. Radiolaria. In: Nordgaard, O. (Ed.), Hydrographical and Biological investigations in Norwegian Fiords, Bergen Museum Skrifter, 114-141.

Keany, J. 1979. Early Pliocene radiolarian taxonomy and biostratigraphy in the Antarctic region. Micropaleontology, 25(1): 50-74.

Kellogg, D.E. 1975. The role of phyletic change in the evolution of Pseudocubus vema (Radiolaria). Paleobiology, 1(4): 359-370.

Kennett, J.P. 1995. A review of polar climatic evolution during the Neogene, based on the marine sediment record. In: Vrba, E. et al. (Eds), Paleoclimate and Evolution with Emphasis on Human Origins. Yale University Press, New Haven, 49-64.

Kozur, H. \& Möstler, H. 1982. Entactinaria suborder nov., a new radiolarian suborder. Geologisch-Paläontlogische Mitteilungen Innsbruck, 11(1): 399-414. 
Lazarus, D.B. 1990. Middle Miocene to Recent radiolarians from the Weddell sea, Antarctica, ODP Leg 113. In: Kennett, J.P. et al. (Eds), Proceedings of the Ocean Drilling Program, Scientific Results, College Station, TX (Ocean Drilling Program), 113: 709-727.

Lazarus, D.B. 1992. Antarctic Neogene radiolarians from the Kerguelen Plateau, Legs 119 and 120. In: Wise, S.W. Jr. et al. (Eds), Proceedings of the Ocean Drilling Program, Scientific Results, College Station, TX (Ocean Drilling Program), 120: 785-809.

Lazarus, D. B. 2001. Late Miocene to early Pliocene radiolarians from glaciomarine drift deposits, ODP Leg 178, Hole 1095B (Bellinghausen Basin, Antarctic Ocean). In: Barker, P.F., Camerlenghi, A., Acton, G.D. \& Ramsay, A.T.S. (Eds), Proceedings of the Ocean Drilling Program, Scientific Results, College Station, TX (Ocean Drilling Program), 178: $1-22$.

Lazarus, D.B., Faust, K. \& Popova-Goll, I. 2005. New species of prunoid radiolarians from the Antarctic Neogene. Journal of Micropaleontology, 24(2): 97-121.

Lees, J.M. 2010. GEOmap: Topographic and Geologic Mapping. R package version $1.5-4$.

Lombari, G. \& Lazarus, D.B. 1988. Neogene cycladophorid radiolarians from North Atlantic, Antarctic, and North Pacific deep-sea sediments. Micropaleontology, 34(2): 97-135.

Moore, T.C. 1973. Method of randomly distributing grains for microscope examination. Jour. Sed. Petrology, 43(3): 904-906.

Müller, J. 1855. Über Sphaerozoum und Thalassicolla. Königlichen Preußischen Akademie der Wissenschaften zu Berlin, Bericht, Jahre 1855: 229-253.

Müller, J. 1858. Über die Thalassicollen, Polycystinen und Acanthometren des Mittelmeeres. Königlichen Preußischen Akademie der Wissenschaften zu Berlin, Abhandlungen, Jahre 1858: 1-62.

Nakaseko, K. 1959. On superfamily Liosphaericae (Radiolaria) from sediments in the sea near Antarctica. Special Publications from the Seto Marine Biology Laboratory, Osaka, Japan, 21pp.

Nigrini, C. 1967. Radiolaria in pelagic sediments from the Indian and Atlantic Oceans. Bulletin of the Scripps Institution of Oceanography, University of California, San Diego, La Jolla, California, 11: 1-125.

Nigrini, C. 1968. Radiolaria from eastern tropical Pacific Sediments. Micropaleontology, 14(1): 51-63.

Nigrini, C. 1977. Tropical Cenozoic Artostrobiidae (Radiolaria). Micropaleontology, 23(3): 241-269.

Nishimura, A. \& Yamauchi, M. 1984. Radiolarians from the Nankai Trough in the Northwest Pacific. News of Osaka Micropaleontologist Special Volume, 6: 1-148.

Nishimura, H. 1990. Taxonomic study on Cenozoic Nassellaria (Radiolaria). Science Report of the Institute of Geosciences, University of Tsukuba, section B, 11: 69-172.

O'Connor, B. 1994. Seven new radiolarian species from the Oligocene of New Zealand. Micropaleontology, 40(4): 337-350.

O’Connor, B. 1997. Lower Miocene Radiolaria from Te Kopua Point, Kaipara Harbour, New Zealand. Micropaleontology, 43(2): 101-128.

O'Connor, B. 1999a. Distribution and biostratigraphy of latest Eocene to latest Oligocene Radiolaria from the Mahurangi Limestone, Northland, New Zealand. New Zealand Journal of Geology and Geophysics, 42: 489-511.

O’Connor, B. 1999b. Radiolaria from the late Eocene Oamaru diatomite, South Island, New Zealand. Micropaleontology, 45(1): 1-55.

Ogane, K., Suzuki, N., Aita, Y., Sakai, T. \& Lazarus, D. 2009. Ehrenberg's Radiolarian Collection from Barbados. In: Tanimura, Y. \& Aita, Y. (Eds), Joint Haeckel and Ehrenberg Project: Reexamination of the Haeckel and Ehrenberg Microfossil Collection as a Historical and Scientific Legacy, National Museum of Nature and Science Monographs, Tokyo, 40: 97-106.

Petrushevskaya, M.G. 1965. Osobennosti 1 konstruktsii skeleta radiolyarii Botryoidae (otr. Nassellaria) [Peculiarities of the construction of the skeleton of radiolarians Botryoidae (order Nassellaria)]. Trudy Zoologicheskogo Instituta, 35: 79-118 [in Russian].
Petrushevskaya, M.G. 1967. Radiolaryii otryadov Spumellaria 1 Nasselaria antarkticheskoi oblasti [Radiolarians of order Spumellaria and Nassellaria of the Antarctic Region]. Issledovaniya Fauny Morei, 4(12): 2-186 [in Russian].

Petrushevskaya, M.G. 1968. Gomologii v skeletakh radiolyarii Nasselaria. 1. Osnovnye dugi v semeistve Cyrtoidea [Homologies in skeletons of nassellarian radiolarians 1. Principal arches of Cyrtoidea]. Zoologicheskii Zhurnal, 47(9): 1296-1310 [in Russian].

Petrushevskaya, M.G. 1971. Radiolyarii nassellaria v planktone mirovogo okeana [Radiolarians of the Ocean]. Issledovaniya Fauny Morei, 9(17): 1-294 [in Russian].

Petrushevskaya, M.G. 1975. Cenozoic radiolarians of the Antarctic, Leg 29, Deep Sea Drilling Project. In: Kennett, J.P., Houtz, R.E. et al. (Eds), Initial Reports of the Deep Sea Drilling Project, Washington (US Govt Printing Office), 29: 541-676.

Petrushevskaya, M.G. 1986. Evolution of the Antarctissa Group. Marine Micropaleontology, 11(1-3):185-195.

Petrushevskaya, M.G. \& Kozlova, G.E. 1972. Radiolaria: Leg 14, Deep Sea Drilling Project. In: Hayes, D.E. et al. (Eds), Initial Reports of the Deep Sea Drilling Project, Washington (US Govt Printing Office), 14: 495-648.

Petrushevskaya, M.G. \& Kozlova, G.E. 1979. Opisanie rodov i vidov Radiolyarii [Description of the radiolarian genera and species]. Issledovaniya Fauny Morei, 23: 86-157 [in Russian].

Popofsky, A. 1908. Die Radiolarien der Antarktis. Deutsche SüdpolarExpedition 1901-1903, 10(Zool., 2): 183-305.

Popofsky, A. 1913. Die Nassellarien des Warmwassergebietes. Deutsche Südpolar-Expedition 1901-1903, 14(Zool., 6): 217-416.

Riedel, W.R. 1967. Some new families of Radiolaria. Geological Society of London, Proceedings, 1640: 148-149.

Sanfilippo, A. \& Riedel, W.R. 1980. A revised generic and suprageneric classification of the Artiscins (Radiolaria). Journal of Paleontology, 54(5): 1008-1011.

Strelkov, A.A. \& Reshetnjak, V.V. 1971. Koloniyalnie radiolyarii Spumellaria mirovogo okeana [Colonial spumellarian radiolarians of the world oceans]. Issledovaniya Fauny Morei, 9(17): 295-373 [in Russian].

Sugiyama, K. 1992. Syscioscenium velamen gen. et sp. nov., a new sethoformid Radiolaria from the lower to middle Miocene of central Japan. Bulletin of the Mizunami Fossil Museum, 19: 215-218.

Sugiyama, K. 1993. Skeletal structures of lower and middle Miocene lophophaenids (Radiolaria) from central Japan. Transactions and Proceedings of the Palaeontological society of Japan, New Series, 169: 44-72.

Sugiyama, K., Nobuhara, T. \& Inoue, K. 1992. Preliminary report on Pliocene radiolarians from the Nobori Formation, Tonohama Group, Shikoku, Southwest Japan. Journal of Earth and Planetary Science, Nagoya University, 39: 1-30.

Takahashi, K. 1991. Radiolaria: flux, ecology and taxonomy in the Pacific and Atlantic. In: Honjo, S. (Ed.), Ocean Biocoenosis Series, Woods Hole, MA, US, Woods Hole Oceanographic Institution, 3: $1-303$.

Takemura, A. 1992. Radiolarian Paleogene biostratigraphy in the southern Indian Ocean, Leg 120. In: Wise, S.W. et al. (Eds), Proceedings of the Ocean Drilling Program, Scientific Results, College Station, TX (Ocean Drilling Program), 120: 735-756.

Vigour, R. \& Lazarus, D.B. 2002. Biostratigraphy of late Miocene-early Pliocene radiolarians from ODP Leg 183 Site 1138. In: Frey, F.A., Coffin, M.F., Wallace, P.J. \& Quilty, P.G. (Eds), Proceedings of the Ocean Drilling Program, Scientific Results, College Station, TX (Ocean Drilling Program), 183: 1-17.

Wang, Y. \& Yang, Q. 1992. Neogene and Quaternary radiolarians from leg 125. In: Fryer, P. et al. (Eds), Proceedings of the Ocean Drilling Program, Scientific Results, College Station, TX (Ocean Drilling Program), 125: 95-112. 